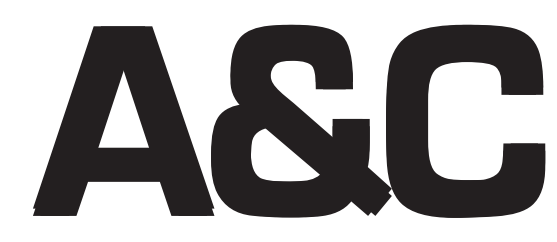

Revista de Direito Administrativo \& Constitucional

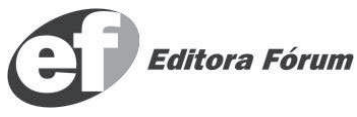

ISSN 1516-3210 


\section{A\&C REVISTA DE DIREITO ADMINISTRATIVO \& CONSTITUCIONAL}

\section{IPDA}

Instituto Paranaense

de Direito Administrativo

Direção Geral

Romeu Felipe Bacellar Filho

Direção Editorial

Paulo Roberto Ferreira Motta

Direção Executiva

Emerson Gabardo

Conselho de Redação

Edgar Chiuratto Guimarães

Adriana da Costa Ricardo Schier

Célio Heitor Guimarães

\section{Conselho Editorial}

Adilson Abreu Dallari (Brasil) Alice Gonzales Borges (Brasil) Antonello Tarzia (Itália)

Carlos Ari Sundfeld (Brasil)

Carlos Ayres Britto (Brasil)

Carlos Delpiazzo (Uruguai)

Cármen Lúcia Antunes Rocha (Brasil)

Celso Antônio Bandeira de Mello

(Brasil)

Clèmerson Merlin Clève (Brasil)

Clovis Beznos (Brasil)

Enrique Silva Cimma (Chile)

Eros Roberto Grau (Brasil)

Fabrício Motta (Brasil)

Guilhermo Andrés Muñoz - in memoriam

(Argentina)

Jaime Rodríguez-Arana Muñoz (Espanha)

Jorge Luís Salomoni - in memoriam
(Argentina)
José Carlos Abraão (Brasil)
José Eduardo Martins Cardoso (Brasil)
José Luís Said (Argentina)
José Mario Serrate Paz (Uruguai)
Juan Pablo Cajarville Peruffo (Uruguai)
Juarez Freitas (Brasil)
Julio Rodolfo Comadira - in memoriam
(Argentina)
Luís Enrique Chase Plate (Paraguai)
Lúcia Valle Figueiredo (Brasil)
Manoel de Oliveira Franco Sobrinho -
in memoriam (Brasil)
Marçal Justen Filho (Brasil)
Marcelo Figueiredo (Brasil)

\author{
Maria Cristina Cesar de Oliveira (Brasil) \\ Nelson Figueiredo (Brasil) \\ Odilon Borges Junior (Brasil) \\ Pascual Caiella (Argentina) \\ Paulo Eduardo Garrido Modesto (Brasil) \\ Paulo Henrique Blasi (Brasil) \\ Paulo Neves de Carvalho - in memoriam \\ (Brasil) \\ Paulo Ricardo Schier (Brasil) \\ Pedro Paulo de Almeida Dutra (Brasil) \\ Regina Maria Macedo Nery Ferrari (Brasil) \\ Rogério Gesta Leal (Brasil) \\ Rolando Pantoja Bauzá (Chile) \\ Sérgio Ferraz (Brasil) \\ Valmir Pontes Filho (Brasil) \\ Weida Zancaner (Brasil) \\ Yara Stropa (Brasil)
}

A246 A\&C Revista de Direito Administrativo \& Constitucional. ano 3, n. 11, jan./mar. 2003. Belo Horizonte: Fórum, 2003.

Trimestral

ano 1, n. 1, 1999 até ano 2, n. 10, 2002 publicada pela Editora Juruá em Curitiba

ISSN 1516-3210

1. Direito Administrativo. 2. Direito Constitucional. I. Fórum.

CDD: 342

CDU: 33.342

(C) 2008 Editora Fórum Ltda.

Todos os direitos reservados. É proibida a reprodução total ou parcial, de qualquer forma ou por qualquer meio eletrônico ou mecânico, inclusive através de processos xerográficos, de fotocópias ou de gravação, sem permissão por escrito do possuidor dos direitos de cópias (Lei nº 9.610, de 19.02.1998).

Editora Fórum Ltda

Editor responsável: Luís Cláudio Rodrigues Ferreira

Av. Afonso Pena, 2770 - 15\%16ªndar - Funcionários

CEP 30130-007 - Belo Horizonte/MG - Brasil

Coordenação editorial: Olga M. A. Sousa

Tel.: 08007043737

Internet: www.editoraforum.com.br

Pesquisa jurídica: Fátima Ribeiro - OAB/MG 74868

Revisora: Lourdes Nascimento

Projeto gráfico e diagramação: Luis Alberto Pimenta

e-mail: editoraforum@editoraforum.com.br

Bibliotecária: Fernanda de Paula Moreira - CRB 2900 - 6a região

Esta publicação está indexada no Ulrich's Periodicals Directory

Os conceitos e opiniões expressas nos trabalhos assinados são de responsabilidade exclusiva de seus autores.

Impressa no Brasil / Printed in Brazil

Distribuída em todo o Território Nacional 


\title{
A teoria do mandado de segurança diante da evolução do direito processual civil
}

\section{Ricardo Marcondes Martins}

Procurador do Município de São Paulo. Doutorando em Direito Administrativo pela PUC/SP. Professor de Direito Administrativo da Faculdade de Direito da PUC/SP.

\begin{abstract}
Resumo: O mandado de segurança deve ser compreendido à luz não da lei ordinária, mas do texto constitucional. O inciso LXIX do art. $5^{\circ}$ da CF não garante a propositura da ação prevista infraconstitucionalmente na Lei $\mathrm{n}^{\mathrm{o}} 1.533 / 51$, garante a tutela mandamental para proteção de direito. Com as modificações do Código de Processo, a tutela mandamental foi estendida ao procedimento ordinário. Diante disso, o rito especial previsto na Lei $\mathrm{n}^{\mathrm{o}} 1.533 / 51$ não subsiste no sistema normativo. Sem embargo, o dispositivo constitucional não tem apenas função enfática: para o exercício da função pública abre-se, além das hipóteses de antecipação previstas no art. 273 do CPC, uma terceira: quando houver direito líquido e certo e o magistrado entender que diante da plausibilidade do direito invocado não se faz necessário, para o deferimento da tutela, ler as informações da autoridade coatora, a defesa da Fazenda e o parecer do Ministério Público.
\end{abstract}

Palavras-chave: Mandado de segurança. Antecipação de tutela. Controle jurisdicional da função pública.

Sumário: 1 Introdução - 2 Origem - 3 História constitucional - 4 Núcleo essencial - 5 Novos rumos do direito processual - 6 Mandado de segurança e o novo direito processual - 7 Lei do mandado de segurança e o novo processo civil - 8 Regime jurídico do controle jurisdicional da função pública - 8.1 Apelação da Administração Pública e efeito suspensivo - 8.2 Participação do Ministério Público - 8.3 Prerrogativas da Fazenda Pública - 8.4 Peculiaridades da antecipação de tutela - $\mathbf{8 . 5}$ Informações da autoridade pública 9 Conclusões - Referências

\section{Introdução}

O Direito Administrativo é o "Direito defensivo do cidadão", "que instrumenta, que arma o administrado, para defender-se contra os perigos do uso desatado do Poder". ${ }^{1}$ De nada adiantaria impor restrições ao exercício do poder - um conjunto de princípios e regras contentivos das prerrogativas estatais - se não houvesse um meio apto a impor o respeito a essas restrições — se não fosse instituído um meio de impor a obediência a esses princípios e regras.

BANDEIRA DE MELLO. Curso de direito administrativo. I-20, p. 46. As palavras do ínclito professor paulista sintetizam do modo mais feliz possível a razão de ser do Direito Administrativo. Toda interpretação deve partir desta diretriz: o Direito Administrativo não se presta a ser arma da Administração, mas escudo e arma do administrado. Esse ponto de partida evita equívocos desastrosos, até hoje comuns, na compreensão de seus institutos.

A\&C R. de Dir. Administrativo \& Constitucional, Belo Horizonte, ano 8, n. 33, p. 47-90, jul./set. 2008 
O descumprimento da ordem jurídica é a razão de ser da função jurisdicional: o sistema imputa ao descumprimento das normas jurídicas a aplicação de uma sanção e atribui essa aplicação aos exercedores da função jurisdicional. Os magistrados têm a magna incumbência de ser a voz do direito, dizer a última palavra sobre a incidência e interpretação das normas jurídicas, eles são verdadeiros oráculos do Direito. Para o cumprimento de tão nobre função é condição logicamente necessária a imparcialidade. Em decorrência dessa exigência, o exercício da função jurisdicional é regido pelo princípio da inércia da jurisdição: esses agentes não atuam de ofício, precisam ser provocados. Tudo, enfim, seria inútil se o sistema não previsse um meio adequado de provocação do exercício da função jurisdicional. Nos Estados de jurisdição una, como o Brasileiro, a função jurisdicional é privativa do Poder Judiciário e a provocação do exercício dessa função dá-se pelo ajuizamento de uma ação judicial.

Daí a importância do estudo do mandado de segurança: se o Direito Administrativo é um meio de proteção do cidadão, o mandado de segurança é o instituto que faz essa proteção real. ${ }^{2}$ A história desse instituto revela, de modo fascinante, a evolução desse jovem ramo da Dogmática. Ao examinar o mandado de segurança sob a perspectiva histórica, o jurista percebe, de modo surpreendentemente claro, como a aludida proteção foi ficando mais sólida, como a arma e o escudo do cidadão foram se tornando mais eficazes e mais poderosos. Revelar esse avanço, apresentar essa evolução a partir de uma exposição obcecada pela síntese: eis o propósito deste estudo.

Os objetivos, contudo, não são nada modestos: pela análise histórica, com atenção especial para a recente evolução do Direito Processual, pretende-se revelar algo que, surpreendentemente, não foi percebido pela doutrina brasileira. Os resultados deste opúsculo apresentam-se como verdadeira novidade, nova proposta científica de compreensão de um instituto fartamente examinado pela doutrina. Trata-se de sincera homenagem aos autores que contribuíram para o desenvolvimento desse tema. O tributo, porém, não está na reprodução acrítica das idéias consagradas e, assim, na estagnação dessas idéias, mas na tentativa de contribuir para o aprimoramento científico de tema que foi tão caro aos doutos.

\footnotetext{
2 Com pena de ouro, o notável Sérgio Ferraz há muito apregoou: "O mandado de segurança tem de ser entendido como uma arma do liberalismo, como uma via basilar das armas do cidadão". Aspectos processuais do mandado de segurança. In: BANDEIRA DE MELLO (Coord.). Curso de mandado de segurança, p. 128.
}

A\&C R. de Dir. Administrativo \& Constitucional, Belo Horizonte, ano 8, n. 33, p. 47-90, jul./set. 2008 


\section{Origem}

Os tratadistas do Código de Napoleão ergueram o sistema jurídico sobre o dogma de que todos os conflitos reduzem-se a um problema patrimonial, todos os bens são equivalentes e, assim, podem ser convertidos em pecúnia. Reflexo disso é o artigo 1.142 do Código Civil Francês, segundo o qual toda obrigação de fazer ou não-fazer resolve-se em perdas e danos, no caso de inadimplemento do devedor. Como todo bem jurídico era conversível em pecúnia, a lide reduzia-se sempre à cobrança de uma indenização, vale dizer, toda ilicitude se convertia num problema de danos patrimoniais, cuja solução se dava pelo ressarcimento pecuniário.

Não tardou para que se percebesse a insuficiência desse modelo. Condicionar a tutela jurisdicional à caracterização de um dano e, pior, limitar essa tutela à condenação ao pagamento de uma indenização pecuniária faz com que os condicionamentos impostos pelo Direito Administrativo tenham pouco valor. Ao descumprimento do sistema normativo restava ao administrado uma inglória prosternação. Por isso, os publicistas logo propugnaram por medidas judiciais contra o mero ilícito. Com efeito: para os atos do Estado, desde cedo, os juristas clamaram por uma tutela contra o ilícito, discrepante da regra em vigor no sistema, de restrição à tutela contra o dano. Perceberam os publicistas que o Estado de Direito só seria real se o administrado pudesse obter a tutela jurisdicional em face da prática do ilícito pelos agentes públicos, independentemente da ocorrência — ou mesmo da real possibilidade de ocorrência — do dano. Pretendeuse garantir aos administrados não o pagamento de uma indenização, mas o efetivo cumprimento das normas jurídicas pelo Estado.

Logo no início do período republicano, em 20.11.1894, foi promulgada a Lei $\mathrm{n}^{\circ} 221$, que, no art. 13, previu a chamada ação sumária especial. O objeto dessa ação era a lesão a direitos individuais por atos das autoridades administrativas da União; ela permitia a suspensão liminar do ato impugnado e visava não à obtenção de uma indenização, mas à invalidação do ato ilícito. Tratava-se de avançada tutela contra o ilícito, diploma normativo inegavelmente à frente do Direito da época, anacronismo esse que muito provavelmente foi a causa de sua ineficácia. Todos concordam que a ação sumária especial da Lei ${ }^{\circ} 221$ não alcançou seu intuito. ${ }^{3}$

\footnotetext{
Foi o que bem ficou registrado no brilhante parecer do deputado Alcântara Machado, transcrito por NUNES. Do mandado de segurança, p. 18-22. Do mesmo modo, para Themístocles Brandão Cavalcanti, os resultados dessa ação "foram deficientes, senão nulos". Do mandado de segurança, p. 51. Cumpre anotar que ambas
} 
Diante do insucesso da Lei $\mathrm{n}^{\mathrm{o}} 221$ restava o problema: garantir uma tutela contra o ilícito praticado pelos agentes públicos. Dentre os juristas brasileiros que lutaram pela instituição dessa tutela destaca-se o inolvidável Rui Barbosa. Inicialmente, o jurista baiano ardorosamente propugnou pela utilização dos interditos possessórios para proteção dos direitos violados pelos agentes estatais. ${ }^{4}$ Nascia uma forte tendência: vários doutrinadores, parlamentares e juízes passaram a defender a ampla utilização dos interditos como garantia dos direitos. ${ }^{5}$

Por outro lado, pelo $§ 22$ do art. 72 da Constituição de 1891 dar-seia habeas corpus "sempre que o indivíduo sofrer ou se achar em iminente perigo de sofrer violência, ou coação, por ilegalidade ou abuso de poder". A semelhança com a redação do inciso LXIX do art. $5^{\circ}$ da Constituição de 1988 não é contingente: a origem do mandado de segurança, a definição de seus traços elementares, está no referido §22. Como o texto constitucional de 1891, ao fixar o objeto do habeas corpus, não se referia expressamente à liberdade de locomoção, à turbação do direito de ir, vir e ficar, muitos passaram a defender que diante da prática de qualquer ilícito pelo Estado, ou seja, diante de toda ilegalidade ou abuso de poder praticado pelos agentes públicos, era possível a impetração de habeas corpus. Essa doutrina ficou conhecida como doutrina brasileira do habeas corpus e marcou a segunda tendência sobre o modo de enfrentar os desmandos estatais.

Surgiram, então, duas correntes: uma de orientação civilista, pela qual a tutela jurisdicional contra o ilícito estatal dava-se pelos interditos possessórios; outra de orientação publicista, pela qual essa tutela dava-se pelo habeas corpus. A segunda corrente tornou-se acentuadamente mais forte do que a primeira, sendo acolhida pelo Supremo Tribunal Federal

as obras, a de Themístocles Brandão Cavalcanti e a de Castro Nunes, são verdadeiros clássicos do tema: a primeira edição foi publicada, respectivamente, em 1934 e 1937, pouco tempo após a positivação constitucional do mandado de segurança. José de Castro Nunes, magistrado de carreira, foi nomeado Ministro do STF em 1940; Themístocles Brandão Cavalcanti seguiu a carreira de Procurador da República e foi nomeado Ministro do STF em 1967. Dada essa notícia histórica, é mister observar que o insucesso da Lei $n^{\circ} 221 / 1894$ marca a eterna luta entre os detentores do poder e os respectivos destinatários. Criam-se institutos para garantir o respeito às restrições impostas ao exercício do poder; esses institutos são enfraquecidos e, após, restabelecidos; encontram-se exceções, afastam-se as exceções encontradas; eles são reduzidos à letra morta e, posteriormente, renascem das cinzas. Essa luta é eterna. Interessante notar que ela se revela com a mesma clareza na história do mandado de injunção, instituído pelo inciso LXXI do art. $5^{\circ}$ da $\mathrm{CF} / 88$.

4 Em 15.07.1896 o ministro da justiça suspendeu ilegalmente os lentes da Escola Politécnica. Rui Barbosa, advogado dos lentes, defendeu que a suspensão ilegal importava turbação na posse do direito e que os interditos possessórios seriam instrumentos judiciários de tutela do direito. É o que informa: BUZAID. Do mandado de segurança, §13, p. 27. A defesa de Rui Barbosa tornou-se um verdadeiro clássico: BARBOSA. Posse dos direitos pessoais.

5 CAVALCANTI. Do mandado de segurança, p. 76-81.

A\&C R. de Dir. Administrativo \& Constitucional, Belo Horizonte, ano 8, n. 33, p. 47-90, jul./set. 2008 
(citam-se, como exemplos: $\mathrm{HC} \mathrm{n}^{\circ} 2.794$, de 11.12.1909; $\mathrm{HC}^{\circ}{ }^{\circ} 2.797$, de 15.12.1909; $\mathrm{HC} \mathrm{n}^{\circ}$ 2.990, de 25.11.1911). Curiosamente, a segunda posição foi calorosamente defendida por Rui Barbosa, ${ }^{6}$ justamente quem, inicialmente, havia sido o mentor da primeira.

No Congresso Jurídico de 1922 iniciou-se um movimento para superar as duas tendências - sobretudo, a segunda, que era dominante - pela criação de um meio novo para o amparo dos direitos individuais, proposta que foi relatada pelo Ministro do STF Edmundo Muniz Barreto. ${ }^{7}$ Apontou-se, inicialmente, a necessidade de uma tutela jurisdicional rápida e eficaz contra a ameaça ou violação do direito, de modo a garantir não uma indenização, mas o efetivo gozo do direito. Observou-se que o habeas corpus historicamente tem por objeto a proteção da liberdade pessoal. Por isso, clamou-se por um instituto semelhante ao recurso de amparo do direito mexicano. ${ }^{8}$ Eis a conclusão: "o incremento da vida judiciária e a necessidade de solução rápida de certas situações de anormalidade, apreciáveis de plano pelos tribunais e incabíveis no remédio do habeas corpus, exigem a criação de um instituto processual capaz de reintegrar o direito violado".

A proposta ganhou força em decorrência da Reforma Constitucional de 03.09.1926. Pela nova redação dada ao referido $§ 22$ do art. 72, dar-seia habeas corpus "sempre que alguém sofrer ou se achar no iminente perigo de sofrer violência por meio de prisão ou constrangimento ilegal em sua liberdade de locomoção". A reforma constitucional importou no sepultamento da doutrina brasileira do habeas corpus. Considerando-se que a orientação civilista de extensão do objeto dos interditos possessórios estava, praticamente, superada, a modificação do texto constitucional importou numa verdadeira lacuna de tutela jurisdicional, num sério enfraquecimento do Estado de Direito: diante da violação dos direitos pelo Estado, restava apenas a busca da indenização. A positivação da proposta formulada no Congresso de 1922 tornou-se, então, necessária.

\footnotetext{
6 Argumentou o emérito Rui Barbosa: se o constituinte quisesse manter o habeas corpus com a feição que ele possuía no Império, teria procedido em relação ao habeas corpus como procedeu, no §31 do art. 72 , relativamente à instituição do Júri. Reza esse preceito: "É mantida a instituição do Júri". Diria, então, o constituinte: "é mantido o habeas corpus". Mas não foi desse modo que o constituinte procedeu: definiu o instituto sem aludir à liberdade física. Sobre essa posição de Rui Barbosa e uma exaustiva crítica, vide: MIRANDA. História e prática do habeas corpus, tomo I, §58, p. 228 et seq. Apesar do esforço de Pontes de Miranda em demonstrar o contrário, a argumentação de Rui é deveras convincente.

7 O relatório é integralmente transcrito tanto por Themístocles Brandão Cavalcanti (Do mandado de segurança, p. 59-62) como por Castro Nunes (Do mandado de segurança, p. 16-17).

8 Há, pois, ligação entre o amparo mexicano e o mandado de segurança brasileiro. Sobre o amparo, consultese: CAVALCANTI. Do mandado de segurança, p. 33-40; BUZAID. Do mandado de segurança, p. 47-64; BARBI. Do mandado de segurança, p. 15-18.
} 
Deu-se com a promulgação da Constituição de 1934: garantiu-se, no art. 113, 33, o mandado de segurança. Pelo texto, dar-se-ia o writ para a defesa de direito, certo e incontestável, ameaçado ou violado por ato manifestamente inconstitucional ou ilegal de qualquer autoridade. Em relação a esse dispositivo, afirmou Castro Nunes: "O preceito entrou em vigor com a própria Constituição, ainda que sem lei que o disciplinasse, ex proprio vigore, pelo princípio da auto-executoriedade (selfenforcing) que acompanha as declarações de direitos". ${ }^{9}$ Plenamente correta a lição do nobre magistrado, pois rezava o segundo período do dispositivo constitucional: "O processo será o mesmo do habeas corpus, devendo ser sempre ouvida a pessoa de direito público interessada". A edição de uma lei infraconstitucional era absolutamente desnecessária e, diante da redação do dispositivo, constitucionalmente discutível: o rito era o do habeas corpus. Todavia, o legislador logo estabeleceu — na Lei ${ }^{\circ}$ 191, de 16.01.1936 — um rito especial para essa ação constitucional, ${ }^{10}$ instituiu um prazo decadencial de 120 dias $\left(\right.$ art. $\left.3^{\circ}\right)$ e vedou a concessão da segurança em quatro hipóteses (art. $\left.4^{\circ}\right)$.

\section{História constitucional}

A Constituição de 1934 teve vida curta, sobreveio a Carta constitucional de 10.11.1937, própria de um período ditatorial. Nela não constou referência ao mandado de segurança: houve, num claro retrocesso, a supressão da garantia constitucional. A Lei no 191/1936, incompatível com o texto constitucional anterior, foi recepcionada pela nova Constituição. ${ }^{11}$ Os obstáculos às restrições legislativas simplesmente desapareceram. Mandado de segurança passou a ser uma simples ação de rito especial prevista na legislação infraconstitucional.

Posteriormente, a Lei ${ }^{\circ} 191$ foi revogada pelo Código de Processo Civil de 1939 (Decreto-Lei no 1.608), que tratou da ação nos artigos 319 a 331. O novo diploma trouxe poucas novidades: manteve o prazo decadencial

\footnotetext{
9 Do mandado de segurança, p. 22.

10 Decorreu do projeto elaborado pelo Senador Alcântara Machado, que na opinião de Themístocles Brandão Cavalcanti era "superior a tudo quanto posteriormente foi feito sobre o assunto" (Do mandado de segurança, p. 101). Percebe-se o claro jogo de poder dantes mencionado: diante da positivação constitucional, seguiuse a limitação legislativa.

11 Pela teoria da recepção as normas infraconstitucionais anteriores à promulgação da atual Constituição consideram-se recepcionadas por esta, desde que com ela compatíveis; há uma espécie de recriação do direito pretérito, o conteúdo das normas anteriores é mantido, mas elas recebem um novo fundamento de validade. Para que a recepção ocorra é irrelevante eventual incompatibilidade da norma com as Constituições pretéritas: as normas recepcionadas são tomadas como dados, não se admite o exame de adequação com as Constituições pretéritas, basta a compatibilidade material com a Constituição vigente. Por todos: MIRANDA. Manual de direito constitucional, tomo II - Constituição, §69, p. 283.
}

A\&C R. de Dir. Administrativo \& Constitucional, Belo Horizonte, ano 8, n. 33, p. 47-90, jul./set. 2008 
dantes instituído (art. 331), manteve, com pontuais alterações, o rol das restrições à concessão da segurança (art. 320). Dentre as modificações, uma merece destaque: pela Lei $n^{\circ} 191$ não era possível a impetração em face de questão puramente política (art. $4^{\circ}$, III), essa restrição não constou do Código de Processo. Assim: pela Lei de 1936 o mandamus era negado para as questões políticas; pelo Decreto-Lei de 1939, era admitido.

A reconstitucionalização ocorreu com o texto subseqüente, de 18.09.1946. Pelo §24 do art. 141 da nova Constituição conceder-se-ia mandado de segurança para proteger direito líquido e certo não amparado por habeas corpus, seja qual for a autoridade responsável pela ilegalidade ou abuso de poder. Interessante a comparação com o texto de 1934: suprimiuse a referência ao rito do habeas corpus, tornando-se possível a recepção do rito especial estabelecido no Código de Processo de 1939. Porém, apesar da crítica de Themístocles Brandão Cavalcanti, ${ }^{12}$ houve avanço: substituiuse a expressão "direito certo e incontestável" por "direito líquido e certo" e suprimiu-se o qualificativo "manifestamente" dantes imputado à ilegalidade ou inconstitucionalidade praticadas. O texto anterior fundamentou o entendimento de que a impetração só era possível em face de questões simples, que não ofereciam complexidade. Diante da nova redação, após muita discussão na doutrina e na jurisprudência, essa posição foi sepultada: a impetração exige tão-somente a demonstração documental dos fatos. Sempre que os fatos relativos à antijuridicidade da conduta imputada ao Estado são provados documentalmente, sendo dispensado qualquer outro meio de prova, há direito líquido e certo. ${ }^{13}$

Os artigos 319 a 331 do Código de Processo de 1939 foram revogados pela Lei $\mathrm{n}^{\circ} 1.533$, de 31.12.1951, cuja vigência mantém-se, segundo muitos, até o presente. O novo diploma não empreendeu alterações substanciais: manteve o rol de restrições $\left(\operatorname{art} .5^{\circ}\right.$ ), manteve o prazo decadencial

\footnotetext{
12 Do mandado de segurança, p. 131.

13 Sobre o conceito de direito líquido e certo, vide: FERRAZ. Mandado de segurança, p. 25-37; FIGUEIREDO. Mandado de segurança, p. 20-22; BARBI. Do Mandado de segurança, p. 53; MEIRELLES. Mandado de segurança, p. 28-29. Vide, em especial: VELLOSO. Conceito de direito líquido e certo. In: BANDEIRA DE MELLO (Org.). Curso de mandado de segurança, p. 69-100. Nos debates que se seguiram à palestra do Min. Velloso, o benemérito Prof. Celso Antônio Bandeira de Mello apresentou conceito irretocável de direito líquido e certo: "aquele que incide sobre fatos evidenciáveis como induvidosos, independentemente de contraditório para o estabelecimento de sua certeza" (Op. cit., p. 92-93). Libertou o conceito da palavra "incontroverso": o direito, pouco importa, pode ser controvertido pela Administração. O ínclito Sérgio Ferraz também apresenta conceito digno de nota: "Diremos que líquido será o direito que se apresenta com alto grau, em tese, de plausibilidade e admissibilidade de seu reconhecimento; e certo aquele que se oferece configurado preferencialmente de plano, documentalmente, sem recurso a dilações probatórias" (Mandado de segurança, p. 34).
} 
de 120 dias (art. 18). Tecnicamente, as regras similares que constavam do Código de 1939 (arts. 320 e 331) não haviam sido recepcionadas pela Constituição de 1946, vale dizer, houve, em rigor, revogação. Em relação à Lei $\mathrm{n}^{\mathrm{o}} 1.533$, o fenômeno é outro: há inconstitucionalidade. Esta, contudo, não foi reconhecida.

A garantia constitucional foi mantida nas Constituições subseqüentes: constou do $\$ 21$ do art. 150 da Constituição de 24.01.1967, do §21 do art. 153 da Emenda Constitucional $n^{\circ} 1$ (na verdade, nova Constituição) de 17.10.1969. Ambos os dispositivos reproduziram, ipsis verbis, a redação da Constituição de 1946. Modificações ocorreram na Constituição vigente, de 05.10.1988: no inciso LXIX do art. $5^{\circ}$ tornou-se expresso que a autoria da ilegalidade ou abuso do poder abrange os agentes de pessoa jurídica no exercício de atribuição do Poder Público; ${ }^{14}$ no inciso LXX instituiu-se o mandado de segurança coletivo.

Outrora ninguém apontava a inconstitucionalidade das restrições legais. Hoje, apostilas desse teor podem ser colhidas aos racimos. O constitucionalismo fortaleceu-se intensamente nas últimas décadas, mais e mais forma-se uma consciência constitucional. ${ }^{15}$ Por isso, não surpreende muitos doutrinadores enxergarem inconstitucionalidades que não eram vistas no passado. ${ }^{16}$ Surpreende, sim, que ninguém tenha notado algo

\footnotetext{
14 Sobre a autoridade coatora do mandado de segurança vide: DALLARI. A autoridade coatora. In: BANDEIRA DE MELLO (Org.). Curso de mandado de segurança, p. 38-68. O conceito identifica-se com o de agente público, na insuperável classificação de Celso Antônio Bandeira de Mello (Curso de direito administrativo, V4-10, p. 238-242), incluída a categoria dos particulares colaboradores da Administração. Como bem observa Adilson Abreu Dallari está clara no texto constitucional essa "universalidade conferida à autoridade coatora" (Op. cit., p. 39). Para os vários desdobramentos do conceito e um denso estudo jurisprudencial, vide: Sérgio Ferraz (Mandado de segurança, p. 98-119) e Lúcia Valle Figueiredo (Mandado de segurança, p. 58-84). Afirma a ilustre professora: "O conceito de agente público viu-se, então, ampliado em nível constitucional, como assinalado, porque doutrinariamente já era bastante amplo" (Op. cit., p. 54). A modificação da redação constitucional, contudo, foi infeliz: a expressão "seja qual for a autoridade responsável", constante das Constituições de 1946, 1967 e 1969, reporta-se ao gênero e, pois, é preferível à especificação de uma das espécies, ocorrida no texto de 1988. Sem embargo, não se pode negar que a especificação facilita a compreensão do gênero.

15 Vide o magistral trabalho de VERDÚ, Pablo Lucas. O sentimento constitucional. Afirma o renomado constitucionalista: "A princípio, o sentimento constitucional consiste na adesão interna às normas e instituições fundamentais de um país, experimentada com intensidade mais ou menos consciente porque se estima (sem que seja necessário um conhecimento exato de suas peculiaridades e funcionamento) que são boas e convincentes para a integração, manutenção e desenvolvimento de uma justa convivência" (2004, p. 75). Fortalece-se no Estado Brasileiro dia-a-dia o sentimento constitucional.

16 Sobre a inconstitucionalidade do prazo de 120 dias, vide: Carlos Mário da Silva Velloso (Conceito de direito líquido e certo. In: BANDEIRA DE MELLO (Org.). Curso de mandado de segurança, p. 85-88); Sérgio Ferraz (Mandado de segurança, p. 222-227); DIAS. Mandado de segurança e decadência: inconstitucionalidade do art. 18 da Lei 1.533/51. Revista Trimestral de Direito Público. O STF, contudo, considera-o constitucional, conforme Súmula n 632: "É constitucional lei que fixa o prazo de decadência para a impetração de mandado de segurança". Sobre a inconstitucionalidade do art. $5^{\circ}$ da Lei $n^{\circ} 1.533$, vide, por todos: Sérgio Ferraz (Mandado de segurança, p. 159-166). Em relação ao tema, afirmou Celso Antônio Bandeira de Mello: "Não
} 
fundamental para a atual compreensão do tema: a discussão sobre eventuais inconstitucionalidades da Lei $\mathrm{n}^{\circ} 1.533$ está hoje superada em face da revogação desse diploma normativo. A explicação dessa assertiva, proposta central deste estudo, exige algumas considerações sobre a natureza do mandamus.

\section{Núcleo essencial}

O que significa a expressão constitucional "conceder-se-á mandado de segurança”? Até poucas décadas os juristas padeciam de um exagerado apego à lei, sofriam do mal do legalismo. O direito era a lei, ou seja, era o conjunto de veículos introdutores de normas abstratas editados pelo Poder Legislativo. Essa identificação do Direito com a lei foi superada pelo constitucionalismo contemporâneo: o direito não se restringe à lei, abrange valores expressa ou implicitamente presentes no texto constitucional. ${ }^{17}$ Pensar o Direito numa perspectiva mais ampla da adotada pelo legalismo não é tarefa fácil, exige enfrentar tendências profundamente enraizadas. Daí a importância deste ponto de partida: conceder mandado de segurança não é julgar procedente a ação prevista numa lei infraconstitucional. Tomar a expressão "conceder mandado de segurança" como julgar procedente a ação legalmente prevista com esse nome é padecer do mal do legalismo, é entender o texto constitucional a partir do texto legislativo.

A compreensão do tema deve ser buscada no próprio texto constitucional, e o ponto de partida é o signo mandado. Na doutrina brasileira, foi Pontes de Miranda quem, em seu célebre Tratado das Ações, aclarou o significado técnico dessa palavra: na ação mandamental pretende-se que o juiz mande praticar o ato, visa-se à expedição de um mandado, de uma ordem, de um mandamento. Distingue-se da ação declarativa, em que se pretende tornar clara (de-clare) uma relação jurídica, iluminar o mundo jurídico para descobrir se existe ou inexiste uma relação jurídica; distingue-se da ação constitutiva, em que se pretende a constituição ou extinção de uma relação jurídica; distingue-se da ação condenatória, em que se supõe que aqueles a quem ela se dirige tenham agido contra o direito, causado dano e mereçam, por isso, ser condenados (com-damnare), reconhecem-se no mundo jurídico

sinto qualquer constrangimento em dizer que considero este art. $5^{\circ}$ inconstitucional, porque ele estabelece um cerceio, uma contenção, que não está estabelecida em dispositivo constitucional”. O ato coator. In: BANDEIRA DE MELLO (Org.). Curso de mandado de segurança, p. 16.

${ }^{17}$ Vem a lume a advertência de Chaïm Perelman: "A prática do direito, seja ela qual for, exige que se leve em consideração interações entre o texto escrito e as reações resultantes de sua aplicação em dado meio. Desprezando essa interação, não se compreende nada da vida do direito, ou seja, da maneira pela qual sua interpretação evolui sob o efeito das mais variadas técnicas jurídicas". Ética e direito, §33, p. 453. 
a danação e o dever de alguém reparar o dano, enfim, condena-se; distingue-se da ação executiva, em que se passa para a esfera jurídica de alguém o que nela devia constar, vai-se onde está o bem, ele é retirado de lá e transferido para a esfera jurídica do autor (ex-sequor, ex-secutio) ${ }^{18}$ Enfim, a tutela mandamental "tem por fito preponderante que alguma pessoa atenda, imediatamente, ao que o juízo manda”. ${ }^{19}$ Etimologicamente, referese à mão, à manus: "com a mão, aponta-se, mas o mandamento refere-se ao movimento da mão e à premência de obedecer". ${ }^{20}$ Fixa-se o ponto de partida: "conceder-se-á mandado de segurança” significa mandar alguém fazer alguma coisa. ${ }^{21}$

O sentido é completado pela expressão "para proteger direito". Celso Antônio Bandeira de Mello há muito percebeu que as criações humanas são definidas pela causa final, ou seja, é a finalidade que configura sua essência. ${ }^{22} \mathrm{E}$, coerentemente, com o costumeiro brilhantismo, o notável

\footnotetext{
18 MIRANDA. Tratado das ações, tomo I, §25, p. 132-135. Em sentido contrário, manifestou-se Alfredo Buzaid. Para o Ministro, o mandado é uma conseqüência da ação, um efeito da decisão; por isso, para ele, a mandalidade não é um objetivo autônomo apto a criar uma nova categoria de ação, ao lado da declaratória, constitutiva e condenatória (Do mandado de segurança, 1989, §36, p. 72-73). O que distingue, para Buzaid, a ação do mandado de segurança das demais é a índole do direito que pretende tutelar. Sob esse prisma, os direitos subjetivos dividem-se em três grupos: a) direitos que devem ser afirmados e provados judicialmente, sob pena de ser rejeitado o pedido formulado pelo autor; b) direitos reconhecidos em documentos que exprimem não só a certeza da obrigação como a liquidez do seu valor; c) direitos líquidos e certos que por sua clareza e evidência não comportam discussão judicial a seu respeito. Para cada tipo de direito há uma ação: ordinária, de execução, mandado de segurança, respectivamente (Op. cit., §37, p. 7475). Ainda segundo o autor, no mandado de segurança podem ser formulados pedidos declaratório, constitutivo e condenatório, e, assim, o mandado pode configurar uma ação declaratória, constitutiva ou condenatória (Op. cit., §37, p. 76). A proposta de Buzaid, muito bem formulada, configura grave equívoco. O mandamento, deveras, é o efeito da ação mandamental, mas, do mesmo modo, a condenação é o efeito da ação condenatória, a constituição é o efeito da ação constitutiva e assim por diante. A teoria de Buzaid não explica o porquê das Súmulas n 269 e n 271 do STF. Reza a primeira: "O mandado de segurança não é substitutivo de ação de cobrança". E a segunda: "Concessão de mandado de segurança não produz efeitos patrimoniais em relação a período pretérito, os quais devem ser reclamados administrativamente ou pela via judicial própria". Dessarte, ao contrário do que supôs Buzaid, não é possível formular pedido condenatório no mandamus, pode-se, tão-somente, pedir a expedição de um mandamento, não a expedição de um título executivo. A proposta de Pontes de Miranda é supinamente mais avançada.

${ }_{19}$ MIRANDA. Tratado das ações, tomo VI, §1, p. 23.

20 Idem, ibidem.

${ }^{21}$ Muito esclarecedora é a doutrina de Ovídio A. Baptista da Silva: "A ação mandamental tem por fim obter, como eficácia preponderante da respectiva sentença de procedência, que o juiz emita uma ordem a ser observada pelo demandado, em vez de limitar-se a condená-lo a fazer ou não fazer alguma coisa. É da essência, portanto, da ação mandamental que a sentença que Ihe reconheça a procedência contenha uma ordem para que se expeça um mandado". E pouco adiante: "A distinção entre sentenças executivas e mandamentais é fundamental: a execução é ato privativo da parte, que o juiz, através do correspondente processo - se a demanda fora condenatória ou desde logo por simples decreto, se a ação desde o início era executiva -, realiza em substituição à parte que deveria tê-lo realizado. Na sentença mandamental, o juiz realiza o que somente ele, como representante do Estado, em virtude de sua estatalidade, pode realizar". Curso de processo civil, v. 2, p. 336-337.

22 Um relógio, por exemplo, só é um relógio se marca as horas; sua causa final, ou seja, marcar as horas, é a essência do relógio, é o que o torna relógio e o difere dos outros objetos. Após enunciar esse exemplo, conclui Celso Antônio Bandeira de Mello: "é a finalidade e só a finalidade o que dá significação às realizações humanas". Discricionariedade e controle jurisdicional, I-41, p. 46-47.
}

A\&C R. de Dir. Administrativo \& Constitucional, Belo Horizonte, ano 8, n. 33, p. 47-90, jul./set. 2008 
professor foi buscar na finalidade a essência do mandado de segurança: ele é um instrumento de proteção do direito, não de restauração do direito. ${ }^{23}$ Por certo: o mandamus busca evitar a prática de um ilícito, sua continuação ou sua repetição e eliminar ou remover a situação de ilicitude. Pretende evitar que o ilícito seja praticado; se o ilícito foi praticado e exauriu seus efeitos, pretende impedir que seja novamente praticado; se o ilícito foi praticado e não exauriu seus efeitos, pretende impedir que continue produzindo efeitos (mandado de segurança preventivo); ademais, se o ilícito foi praticado, pretende removê-lo, vale dizer, fazer com que sejam tomadas as providências necessárias para afastar ou desfigurar a situação de ilicitude (mandado de segurança repressivo). Não pretende reparar o dano.

Com esses esclarecimentos tem-se o sentido completo da expressão "conceder-se-á mandado de segurança”. Significa: a autoridade jurisdicional expedirá uma ordem à autoridade competente (chamada de autoridade coatora) para que ela não pratique a ilicitude e, se esta já foi praticada, para que ela adote as medidas necessárias à remoção da ilicitude. ${ }^{24}$ Insistese: o mandado não se destina a reparar o dano.

\section{Novos rumos do direito processual}

Até bem pouco tempo, mais precisamente, até o início da década de 90, a tutela contra o ilícito era excepcional, a regra era a tutela contra o dano. Na verdade, pela regra geral, o ilícito identificava-se integralmente com o dano, na maioria dos casos só havia tutela jurídica contra a ocorrência deste, as pessoas só tinham interesse para ingressar em juízo quando sofriam dano ou quando houvesse concreta ameaça de sofrê-lo. Como todo bem jurídico era conversível em pecúnia, a lide reduzia-se sempre à cobrança de uma indenização, vale dizer, toda ilicitude se convertia num problema de danos patrimoniais, cuja solução se dava pelo ressarcimento pecuniário.

\footnotetext{
23 "É claro que, se se adota este vetor interpretativo, de que a função do mandado de segurança é, sobretudo, a de proteger o direito, defender o direito, abrigar o direito, certamente a sua função principal residirá em deter o comportamento agressivo ao direito e não apenas na função de proporcionar, a alguém lesado, a possibilidade de obter a restauração de um direito que já foi ferido". BANDEIRA DE MELLO. O ato coator. In: (Org.). Curso de mandado de segurança, p. 9.

24 Oportuna, mais uma vez, a lição de Celso Antônio Bandeira de Mello: o mandado de segurança não se volta apenas contra atos jurídicos, volta-se também contra fatos jurídicos (O ato coator, 1986, p. 10-11). Pode voltar-se contra omissão administrativa, condutas criminosas, execução material de atos administrativos, atos administrativos inexistentes, contra, enfim, fatos administrativos. A impetração não depende da configuração de um ato administrativo, no caso, de um ato inválido. Feita essa advertência, em relação aos atos administrativos torna-se claro o intuito do mandamus: evitar que um ato inválido seja editado, novamente editado ou executado; obter a correção do ato inválido. Não pretende obter a reparação dos danos causados pela execução do ato inválido.
}

A\&C R. de Dir. Administrativo \& Constitucional, Belo Horizonte, ano 8, n. 33, p. 47-90, jul./set. 2008 
O mandado de segurança consistia numa exceção do sistema: se houvesse direito líquido e certo - direito com base fática demonstrável de plano, sem necessidade de dilação probatória - e a ilicitude fosse praticada por agente público, o sistema garantia a tutela jurisdicional contra o lícito em si, independente da ocorrência do dano. E se não houvesse direito líquido e certo? E se a ilicitude não fosse praticada por agente público? Ressalvada alguma previsão legal específica, incidia a regra geral: somente haveria a tutela jurisdicional contra a ocorrência do dano, garantia-se tão-somente o pagamento de pecúnia, de indenização em face da ocorrência do dano.

O direito processual brasileiro modificou-se muito nas duas últimas décadas, a mudança foi tão grande que caracterizou verdadeira revolução conceitual. Diante dela, grande parte dos juristas tem, ainda hoje, dificuldade em assimilar a novidade. Na doutrina brasileira, coube ao processualista Luiz Guilherme Marinoni denunciar a distorção do sistema antigo e efetuar, a partir dessa denúncia, a reconstrução do direito processual civil. Sua doutrina libertou o direito processual dos dogmas do direito romanonapoleônico, acentuadamente privatista e exclusivamente patrimonialista. ${ }^{25}$ Pode-se afirmar que o direito positivo brasileiro incorporou a doutrina de Marinoni: afastou a idéia de que todos os bens são equivalentes e devem ser convertidos em pecúnia, chamada por Marinoni de princípio da abstração das pessoas e dos bens; ${ }^{26}$ a tutela pelo equivalente em dinheiro, além de deixar de ser exclusiva, passou a ser secundária. Primeiro, há a desvinculação entre o ilícito e o dano e a generalização das tutelas contra o ilícito, além das tradicionais tutelas contra o dano; segundo, o sistema jurídico passa a dar primazia à tutela específica em relação à tutela pelo equivalente em pecúnia.

O marco desse avanço ocorreu com a vigência da Lei Federal $n^{\circ}$ 8.952, de 13.12.1994, que deu nova redação ao art. 273 do Código de Processo Civil vigente (Lei no 5.869/1973 - CPC), possibilitando ao magistrado, independentemente da natureza do direito, no rito ordinário, antecipar

\footnotetext{
25 MARINONI. Técnica processual e tutela dos direitos, p. 58 et seq.; Tutela específica: arts. 461, CPC e 84, CDC, p. 17 et seq. Afirma o magno jurista: "Existe um dogma — de origem romana — no sentido de que a tutela ressarcitória é a única forma de tutela contra o ilícito civil. Isso quer dizer que a unificação entre as categorias da ilicitude e da responsabilidade civil, já realizada no direito romano, percorreu a história do direito, inclusive do direito processual civil, sem suscitar maior inquietude por parte da doutrina. Pior do que isso: chegou-se a identificar o ilícito com o ressarcimento em dinheiro" (Técnica processual e tutela dos direitos, 2004, p. 65). Em outra obra, observa: "No mercado, como é sabido, pouco importam as qualidades do sujeito ou as dos seus bens, de modo que a tutela ressarcitória, ao expressar apenas o custo econômico do valor da lesão, mantinha íntegros os mecanismos do próprio mercado, sem alterar a sua lógica" (Tutela específica, p. 18).

${ }^{26}$ MARINONI. Técnica processual..., p. 58; Tutela específica, p. 35.
}

A\&C R. de Dir. Administrativo \& Constitucional, Belo Horizonte, ano 8, n. 33, p. 47-90, jul./set. 2008 
a tutela jurisdicional. Essa antecipação exige a presença de dois pressupostos: a) verossimilhança da alegação; b) fundado receio de dano irreparável ou de difícil reparação ou caracterização do abuso do direito de defesa ou do manifesto propósito protelatório do réu. A Lei n ${ }^{0}$ 10.444/2002 acrescentou o $\S 6^{\circ}$ ao art. 273, tornando expressa outra hipótese de concessão da antecipação de tutela: quando um ou mais dos pedidos cumulados, ou parcela deles, mostrar-se incontroverso. A Lei no 8.952/94 também alterou a redação do art. 461 do CPC, impondo ao juiz a concessão, na ação que tenha por objeto o cumprimento da obrigação de fazer ou não-fazer, da tutela específica e a determinação das providências necessárias que assegurem o resultado prático equivalente. A conversão em perdas e danos passou a ser admitida apenas se houver pedido do autor ou tornar-se impossível a tutela específica ou a obtenção do resultado prático correspondente. Ambos os dispositivos, o art. 273 e o art. 461 do Código de Processo, modificaram as bases do processo civil brasileiro: a tutela contra o ilícito deixou de ser exceção, passou a ser vulgarmente admitida, podendo ser pleiteada no rito ordinário. ${ }^{27}$

É interessante observar que o artigo 85 do Código de Defesa do Consumidor (Lei $\mathrm{n}^{\circ}$ 8.078/90) foi vetado pelo Presidente da República. O dispositivo permitia a propositura de ação mandamental contra atos ilegais ou abusivos de pessoas físicas ou jurídicas que lesem direito líquido e certo, individual, coletivo ou difuso do consumidor. Entendeu o Chefe do Executivo que a extensão da tutela mandamental a situações de direito privado é incompatível com sua índole constitucional. ${ }^{28}$

\footnotetext{
27 Essa revolução iniciou-se, na verdade, em 11.09.1990, com a promulgação da Lei nº 8.078, denominada de Código de Defesa do Consumidor. O artigo 84 desse diploma possui redação similar à dada ao art. 461 do CPC pela Lei n 8.952/94. Quer dizer: nas ações relativas aos direitos dos consumidores que têm por objeto obrigações de fazer e não-fazer, passou-se a admitir a antecipação da tutela e a utilização de medidas executivas para garantir o cumprimento específico da obrigação, cumprimento esse que se tornou a regra. Registra-se: a revolução conceitual do processo civil brasileiro iniciou-se com a promulgação do avançado Código Brasileiro de Defesa do Consumidor. Daí a justa homenagem aos autores do Anteprojeto que resultou na Lei no 8.078: Ada Pellegrini Grinover, Antônio Herman de Vasconcellos e Benjamin, Daniel Roberto Fink, José Geraldo Brito Filomeno, Kazuo Watanabe, Nelson Nery Júnior e Zelmo Denari. Esse grupo teve grande responsabilidade pelos recentes avanços do processo brasileiro, avanços de proporções inigualáveis na história do direito pátrio. O grupo comentou o Código, gerando obra de leitura obrigatória: Código brasileiro de defesa do consumidor: comentado pelos autores do anteprojeto. Sem embargo, o jurista que mais contribuiu para essa revolução foi, sem dúvida nenhuma, Luiz Guilherme Marinoni: em 1990, ele defendeu o instituto da antecipação de tutela em sua dissertação de mestrado (Tutela cautelar e tutela antecipatória. São Paulo: Revista dos Tribunais, 1992). A doutrina de Marinoni serviu de base para a reforma de 1994 e para as posteriores.

${ }^{28}$ Sobre o tema, vide os comentários de Kazuo Watanabe in: Grinover et al. Código brasileiro de defesa do consumidor, p. 660. Interessante o desabafo do aclamado processualista: "É simplesmente espantoso o argumento! Revela, quando menos, uma total insensibilidade a toda linha evolutiva do Direito Processual moderno" (Idem, p. 661). Há que se fazer uma ressalva: se até hoje, quase vinte anos após a promulgação
} 
Após a reforma do Código de Processo Civil pela Lei no 8.952/94, esse veto tornou-se inútil: desde então passou a ser tranqüilamente possível o ajuizamento de ação mandamental em face da violação de direito por quem não esteja no exercício de função pública. Dessarte: a nova redação dos artigos 273 e 461 do CPC permite pleitear ao juiz a expedição de uma ordem, de um mandamento, para que alguém, havendo fundado receio, não viole o Direito ou, diante da violação, tome as medidas necessárias para remover a ilicitude praticada. A tutela mandamental passou a ser possível nos casos em que a ilicitude não seja praticada por agente público e, mais, nos casos em que não haja direito líquido e certo. A jurisprudência não permite que o jurisdicionado denomine sua ação de mandado de segurança, ele deve dar outro nome: ação de cumprimento de obrigação de fazer, por exemplo. Observado esse requisito de ordem formal, decorrente da incompreensão do estado atual do tema ora estudado, o pedido de tutela mandamental é perfeitamente admitido no rito ordinário, seja qual for a natureza do direito, seja quem for o responsável pela ilegalidade, haja ou não liquidez e certeza.

A revolução conceitual mencionada decorreu da promulgação de leis ordinárias, infraconstitucionais. Contudo, os institutos da antecipação de tutela e da tutela da obrigação específica passaram a ser considerados desdobramentos do princípio constitucional da efetividade da tutela jurisdicional, positivado no inciso XXXV do art. $5^{\text {o }}$ da Constituição de $1988 .{ }^{29} \mathrm{~A}$ tutela efetiva contra o ilícito - e, por conseguinte, a tutela antecipada — tem, pois, status constitucional.

Antes de dar o passo seguinte, é mister esclarecer: de longa data o direito processual brasileiro admite a chamada tutela cautelar. Esta, contudo, tem natureza precisa: garantir o resultado da demanda, vale dizer, garantir que a tutela jurisdicional, ao final deferida, seja exeqüível ou, ainda, impedir que a ação perca seu objeto. ${ }^{30}$ Se a ação destinava-se, apenas, a obter a reparação do dano, a cautelar só poderia obter a garantia da reparação do

do CDC, essa linha evolutiva não foi assimilada com facilidade por muitos juristas, imagine-se a dificuldade naquela época, antes da vigência do CDC. O veto, apesar de configurar um erro grosseiro de compreensão do direito, foi perfeitamente compreensível.

29 MARINONI. Técnica processual..., p. 179 et seq.

${ }^{30}$ Cai a lanço a lição de Humberto Theodoro Júnior: "Na verdade, o processo principal busca tutelar o direito, no mais amplo sentido, cabendo ao processo cautelar a missão de tutelar o processo, de modo a garantir que o seu resultado seja eficaz, útil e operante. Não se pode, evidentemente, entender o processo cautelar senão ligado a um outro processo, posto que as medidas preventivas não são satisfativas, mas apenas preservativas de situações necessárias para que o processo principal alcance resultado realmente útil". Curso de direito processual civil, v. II, p. 335.

A\&C R. de Dir. Administrativo \& Constitucional, Belo Horizonte, ano 8, n. 33, p. 47-90, jul./set. 2008 
dano. Antes da revolução mencionada, o sistema, em regra, não permitia a tutela contra o ilícito e, pois, não permitia a garantia de que o ilícito não seria praticado. Permitia apenas a tutela contra o dano e, pois, a garantia de que, se a ação fosse julgada procedente, o dano seria reparado. Assim, a ampla admissibilidade da tutela cautelar não importava na viabilidade da tutela contra o ilícito. Sem embargo, diante da insuficiência do sistema, os juristas pretenderam utilizar as cautelares como meio de obtenção de efetiva proteção do direito, ou melhor, como substitutivo do instituto da antecipação de tutela. ${ }^{31}$ Diante da insuficiência do direito processual, para a efetiva proteção dos direitos, no direito público invocavam-se os interditos possessórios e o habeas corpus, e no direito privado, as cautelares. A instituição do mandado de segurança atendeu a primeira invocação, a instituição da antecipação da tutela atendeu a segunda. ${ }^{32}$

\section{Mandado de segurança e o novo direito processual}

Ao estudar o mandado de segurança os juristas desprezam, parcial ou totalmente, os avanços do direito processual. Impõe-se a pergunta: quais as conseqüências da admissibilidade ampla e irrestrita da tutela mandamental no rito ordinário? A resposta, apesar de óbvia, não foi notada nem pela doutrina nem pela jurisprudência pátrias. A Lei $n^{\circ}$ 1.533/51 estabelecia um rito especial para a tutela mandamental; com a alteração do Código de Processo, tornou-se possível a tutela mandamental no rito ordinário. Conseqüência lógica: houve a revogação implícita da Lei $\mathrm{n}^{\mathrm{O}}$ 1.533/51. Se é possível pleitear a segurança no rito ordinário, não há mais sentido na subsistência do rito especial. Enfim: a modificação do CPC - mais especificamente, a nova redação dos arts. 273 e 461 — importou na revogação da Lei do Mandado de Segurança, revogação essa não percebida pela comunidade jurídica.

Conceder mandado de segurança, nos termos dantes fixados, é "expedir ordem para proteção do direito". Hoje essa ordem pode ser

\footnotetext{
31 Exemplo notório dessa tendência é a doutrina de Ovídio Baptista da Silva. O notável processualista afastavase da doutrina dominante e considerava que o objeto das cautelares é não a tutela do processo, mas a proteção de um direito da parte. Do processo cautelar, p. 83. A teoria da ação cautelar de Ovídio, formulada antes das reformas processuais de 1994, tornava despicienda a instituição da antecipação da tutela, pois a incorporava integralmente. Valia-se, contudo, de uma distinção teórica sutil: "Daí por que as liminares não poderão ser tidas como medidas antecipatórias, porque elas antecipam efeitos executivos ou mandamentais - que são resultados de fato e não normativos —-, mas não antecipam juízos sobre a existência ou não existência do direito provisoriamente realizado pela medida liminar" (Op. cit., p. 59).

32 Não sem razão observou Marinoni: "O art. 273, ao tornar possível a antecipação da tutela no processo de conhecimento, confere ao cidadão um instrumento processual semelhante ao mandado de segurança". A antecipação da tutela na reforma do processo civil, p. 45.
} 
expedida no rito ordinário. O inciso LXIX do artigo $5^{\circ}$ da Constituição da República não garante a propositura da ação prevista infraconstitucionalmente na Lei ${ }^{\circ} 1.533 / 51$, garante a tutela mandamental para proteção de direito. Com as modificações do Código de Processo, a tutela mandamental tornou-se ordinária, foi estendida ao procedimento ordinário. ${ }^{33}$ Conclui-se, enfim: o rito especial previsto na Lei $\mathrm{n}^{\mathrm{o}} 1.533 / 51$ não subsiste no sistema normativo.

Diante dessa conclusão, poder-se-ia indagar sobre a utilidade do inciso LXIX do art. $5^{\circ}$ do Texto Maior. Deveras, se a irrestrita ou ordinária tutela contra o ilícito é imposta pelo inciso XXXV do art. $5^{\circ}$, se do princípio constitucional da tutela jurisdicional efetiva decorre o direito à concessão de segurança para proteção de direito, independentemente da caracterização do exercício da função pública, é pertinente indagar sobre a utilidade da previsão autônoma do mandado de segurança no mencionado inciso LXIX. É lição elementar de hermenêutica que não se presumem palavras inúteis no texto normativo, ainda mais no texto constitucional. Nada impede que a enunciação constitucional tenha mera função enfática, em diversos dispositivos do texto constitucional essa função está presente. ${ }^{34}$ No caso do mandado de segurança, porém, a função não é apenas enfática: o dispositivo alarga, quando se trata do exercício da função pública, as hipóteses de antecipação de tutela.

Dessarte: o valor do dispositivo não está, propriamente, na expressão “conceder-se-á mandado de segurança para proteção de direito", porque essa expressão é uma decorrência implícita do princípio da efetividade da tutela jurisdicional. O valor real do dispositivo está no complemento:

\footnotetext{
33 Em rigor, a Lei no $1.533 / 51$ não foi revogada pela Lei n 8.952/94. Ela não foi recepcionada pelo texto constitucional. Isso porque, como dantes afirmado, as mencionadas modificações processuais são consideradas desdobramentos do texto constitucional, impostas pelo princípio da efetividade da tutela jurisdicional, positivado no inciso XXXV do art. $5^{\circ}$ da CF. Da evolução da própria compreensão do direito processual concluiu-se que a restrição da tutela contra o ilícito era incompatível com o texto constitucional e, por conseguinte, a Lei no $1.533 / 51$, cuja razão de ser pressupõe essa restrição, também o é e, assim, não foi recepcionada.

34 A Constituição Brasileira de 1988 é posterior a um longo período ditatorial. Esse fato explica a preocupação do constituinte em enfatizar determinados direitos e garantias. Resplandece que o constituinte exerceu a função enfática de duas maneiras: 1) Pela simples repetição do mesmo termo. Mencionou o princípio da igualdade no preâmbulo; no inciso IV do art. $3^{\circ}$; no caput do art. $5^{\circ}$, no inciso XXI do art. 37; no inciso II do art. 150; no inciso I do art. 206 e no inciso IV, $\S 3^{\circ}$, do art. 227 - a repetição tem tão-somente função enfática. 2) Pela utilização de dois termos, em que um é abrangido pelo outro. Exemplo típico dá-se no inciso LXXI do art 50, ao afirmar que o mandado de injunção conceder-se-á "sempre que a falta de norma regulamentadora torne inviável o exercício dos direitos e liberdades constitucionais e das prerrogativas inerentes à nacionalidade, à soberania e à cidadania" - evidente que nos direitos constitucionais já estão incluídas as liberdades e as prerrogativas inerentes à nacionalidade, à soberania e à cidadania, a reiteração, também aí, teve função enfática.
}

A\&C R. de Dir. Administrativo \& Constitucional, Belo Horizonte, ano 8, n. 33, p. 47-90, jul./set. 2008 
"para proteção de direito líquido e certo". Ora, nos termos dantes afirmados, a antecipação de tutela pode ser deferida em duas hipóteses. Na primeira, quando estiverem presentes dois pressupostos: a) verossimilhança da alegação; b) fundado receio de dano irreparável ou de difícil reparação ou caracterização do abuso do direito de defesa ou do manifesto propósito protelatório do réu. Na segunda, quando um ou mais dos pedidos cumulados, ou parcela deles, mostrar-se incontroverso. Para o exercício da função pública abre-se, além dessas duas hipóteses, ${ }^{35}$ uma terceira: quando houver direito líquido e certo e o magistrado entender que diante da plausibilidade do direito invocado não se faz necessário, para o deferimento da tutela, ler as informações da autoridade coatora, a defesa da Fazenda e o parecer do Ministério Público.

Perceba-se: quando se tratar de antijuridicidade - expressão que compreende a ilegalidade e o abuso de poder - cometida no exercício de função pública, a antecipação da tutela pode ser deferida ainda que não haja periculum in mora - fundado receio de dano irreparável ou de difícil reparação -, abuso do direito de defesa ou controvérsia. Quando houver direito com base fática demonstrável de plano, sem necessidade de dilação probatória, o magistrado deve examinar se é o caso de conceder a segurança de plano e, assim, antecipar a tutela, ou se deve aguardar as informações da autoridade coatora, a defesa da Administração Pública e o parecer do Ministério Público. ${ }^{36}$ Prevalece na doutrina que o periculum in mora é pressuposto para o deferimento da liminar no mandado de segurança. ${ }^{37}$ Discorda-se: se o magistrado considerou inconstitucional um tributo em

\footnotetext{
${ }^{35}$ Houve grande resistência por parte de alguns processualistas à antecipação da tutela jurisdicional em face da Fazenda Pública. Dentre os vários argumentos invocados, juristas de renome viam no reexame necessário, previsto no artigo 475 do CPC, e no regime de precatórios, previsto no artigo 100 da Constituição, óbices incontornáveis. Sobre as discussões a respeito, vide VIANA. Efetividade do processo em face da Fazenda Pública, p. 124 et seq. Os dois argumentos foram sustentados com ênfase por GIANESINI. Tutela antecipada e execução provisória contra a Fazenda Pública. In: SUNDFELD; BUENO (Coord.). Direito processual público, p. 170-180. Hoje, porém, felizmente, a questão está superada. Ninguém mais duvida do cabimento da tutela antecipada contra a Administração. A remessa oficial jamais foi óbice ao deferimento de liminar em mandado de segurança: o parágrafo único do artigo 12 da Lei $n^{\circ} 1.533 / 51$ submetia as sentenças concessivas da ordem ao reexame necessário e, nem por isso, é ou foi considerado um óbice ao deferimento da liminar. O sistema de precatórios é, de fato, um obstáculo (não absoluto, podendo ser afastado pela ponderação das circunstâncias fáticas e jurídicas) à antecipação da tutela pecuniária, mas em nada prejudica a antecipação quando a providência exigida da Fazenda seja um fazer, não-fazer ou entregar coisa. Por fim, o legislador reconheceu a aplicabilidade à Fazenda da antecipação da tutela jurisdicional na inditosa Lei nº 9.494/97.

${ }^{36}$ A presença do direito líquido e certo não é suficiente para o deferimento da liminar: o magistrado deve examinar as razões invocadas pelo administrado e decidir se deve ou não aguardar as informações da autoridade coatora, a defesa da Administração Pública e o parecer do parquet. O direito liquido e certo é condição suficiente para a concessão da segurança, mas não para o deferimento da liminar. Esta exige um grau de plausibilidade que permita a dispensa da leitura das informações, da defesa e do parecer.

37 Por todos, vide FERRAZ. Mandado de segurança, p. 252 et seq.
} 
sentenças anteriormente proferidas, não há porque aguardar as informações da autoridade coatora, a defesa do Fisco ou o parecer do parquet; deve antecipar a tutela, ainda que não haja receio de dano irreparável ou de difícil reparação.

\section{Lei do mandado de segurança e o novo processo civil}

Sustenta-se, nos termos expostos, que as modificações do direito processual brasileiro, decorrentes de um significativo aprimoramento científico e de pontuais reformas legislativas, importaram na revogação da Lei $\mathrm{n}^{\mathrm{o}} 1.533 / 51$. Em rigor, observou-se, o fenômeno não é propriamente de revogação, mas de não-recepção, pois essas modificações são consideradas desdobramentos do próprio texto constitucional, da garantia da efetividade da jurisdição. A extensão da tutela mandamental ao rito ordinário tornou o rito especial da Lei $\mathrm{n}^{\mathrm{o}}$ 1.533/51 incompatível com o texto constitucional. Essa incompatibilidade, interessante notar, não é de ordem substancial, mas de ordem lógica. O rito em si não contradiz o texto maior, a contradição decorre da existência de um rito especial para a tutela mandamental quando esta pode ser pleiteada no rito ordinário. Em suma: a retirada da Lei $\mathrm{n}^{\circ} 1.533 / 51$ deu-se pelo avanço científico, pela incompatibilidade lógica com esse avanço.

Para testar o acerto dessa conclusão é mister supor sua incorreção. Admita-se, seguindo a doutrina e a jurisprudência, que a Lei $\mathrm{n}^{0}$ 1.533/51 subsiste no sistema normativo. Configurado o direito líquido e certo, o administrado possuiria duas medidas jurisdicionais de impugnação da ilegalidade ou do abuso de poder praticado pelo agente público. Poderia impetrar mandado de segurança pelo rito especial da Lei $\mathrm{n}^{0} 1.533 / 51$ ou propor ação de cumprimento de obrigação de fazer, com pedido de antecipação de tutela, pelo rito ordinário. Ambas as possibilidade são hoje tranqüilamente admitidas pela doutrina e pela jurisprudência. ${ }^{38}$

\footnotetext{
${ }^{38}$ Na doutrina averba Cássio Scarpinella Bueno: "Em consonância com o quanto sustentamos no item 2.1, supra, o art. $1^{\circ}$ da medida [refere-se à Medida Provisória 1.570/97] (e, posteriormente, da Lei 9.494/97), ao se referir, expressamente, à Lei 4.348/64 e à Lei 5.201/66, acabou por admitir que, à mingua de direito líquido e certo, a ação de conhecimento onde inicial ou incidentalmente seja requerida a antecipação de tutela é veículo adequado não só para o atingimento da pretensão do particular contra o Poder Público, mas, também, para que a fruição desta pretensão possa ser antecipada, comprovados, evidentemente, os pressupostos fático/jurídicos condutores da concessão daquela medida”. Liminar em mandado de segurança: um tema com variações, p. 56. Na jurisprudência, citam-se, como exemplos de admissibilidade da propositura, em face da Fazenda Púlica, de ação com rito ordinário com pedido de antecipação de tutela para obtenção da tutela mandamental, os seguintes julgados: STJ, $1^{\text {a }}$ T., AgRg no Recurso Especial n 635.649-SC (2004/ 0004158-3), Rel. Min. Luiz Fux, j. 21.10.2004; Recurso Especial n 796.215-RS (2005/0184183-7), Rel. Min. José Delgado, j. 13.12.2005.
}

A\&C R. de Dir. Administrativo \& Constitucional, Belo Horizonte, ano 8, n. 33, p. 47-90, jul./set. 2008 
Pois bem, o rito da Lei $\mathrm{n}^{\circ} 1.533 / 51$ apresenta algumas peculiaridades: o prazo para a impetração é de 120 dias, nos termos do art. 18; a autoridade coatora $^{39}$ é notificada para apresentar informações no prazo de 10 dias, nos termos do art. $7^{\circ}$, I, combinado com o art. $1^{\circ}$, "a", da Lei n ${ }^{\circ} 4.348 / 644^{40}$ a pessoa jurídica de direito público é citada ${ }^{41}$ para apresentar contestação

39 Autoridade coatora é "a que efetivamente pratica o ato lesivo". FERRAZ. Mandado de Segurança, p. 98. É a que praticou a ilegalidade ou abuso de poder. Esse conceito faz supor que a autoridade coatora é a pessoa física. Esta, contudo, é absolutamente irrelevante. A sabendas, averbou Adilson Abreu Dallari: "Se o diretor de um departamento pratica um ato e no dia seguinte é substituído, por outro diretor, que até não concorda com aquele ato praticado, o mandado de segurança será impetrado contra o diretor do órgão, independentemente da pessoa física. A autoridade não é a pessoa física, autoridade é um feixe de atribuições, autoridade é aquela pessoa que, reunindo esse feixe de atribuições, pratica o ato, mas o que importa aí é o feixe de atribuições" (A autoridade coatora. In: BANDEIRA DE MELLO (Org.). Curso de mandado de segurança, p. 44-45).

40 As informações da autoridade coatora não têm natureza de defesa. A autoridade coatora não é parte no mandado de segurança, é mera informante. Há grande controvérsia na doutrina e na jurisprudência sobre o assunto, mas, com todo respeito pelos que possuem entendimento diverso, essa é a melhor posição. Hoje está pacificada no STF, citando-se a título de exemplo: "Mandado de Segurança - Autoridade coatora e parte passiva - Concessão da ordem - Publicação. Cumpre distinguir o autor do ato impugnado da pessoa jurídica que, concedida a ordem, suportaria as conseqüências do pronunciamento judicial e que, portanto, há de ter, na relação processual, a posição de parte passiva. A publicação do acórdão deve fazer-se, como dispõe o artigo 236 do Código de Processo Civil, com alusão à pessoa jurídica responsável e o respectivo representante processual". 1ª T., Al-AgR n 447041/PE, Rel. Min. Marco Aurélio, j. 21.09.2004, v.u., DJ, p. 29, 19 nov. 2004; "Recurso Extraordinário. Mandado de segurança. Autoridade coatora. Ilegitimidade para interpor recurso extraordinário. 1. A jurisprudência do Supremo Tribunal Federal é no sentido de que a pessoa jurídica de direito público a que pertence a autoridade ou o órgão tido como coator é o sujeito passivo do mandado de segurança, razão por que é ele o único legitimado para recorrer da decisão que defere a ordem". 2a T., RE-AgR n 412430/MS, Rel. Min. Ellen Gracie, j. 13.12.2005, v.u., DJ, p. 40, 17 mar. 2006. Na doutrina: FERRAZ. Mandado de segurança, p. 86, 119; FIGUEIREDO. Mandado de segurança, p. 54-55.

${ }^{41}$ Ré no mandado de segurança é a pessoa jurídica de direito público a que pertence a autoridade tida por coatora ou, noutros termos, é a pessoa que suportará as conseqüências do pronunciamento judicial caso a segurança seja concedida. Não é, como afirmado, a própria autoridade coatora — mera informante. A Lei no 1.533/51 previu, infelizmente, apenas a notificação da autoridade coatora, nada dizendo sobre a citação da ré. A omissão gerou várias correntes e desastrosos equívocos. Daí a necessidade de enfatizar: deve a pessoa jurídica ser citada. Por todos: FERRAZ. Mandado de Segurança, p. 87. Ressalta-se que a autoridade coatora, como não é parte, não precisa fazer-se representar por advogado, presta as informações em seu nome. A pessoa jurídica à qual ela está ligada - que não é necessariamente de direito público, pois a autoridade coatora pode ser um particular que colabora com a Administração Pública e, pois, exerce função pública - diretor de escola, concessionário, permissionário, etc. — deve fazer-se representar por advogado. Calha à fiveleta o autorizado escólio de Sérgio Ferraz: "De toda a sorte, a Constituição põe um pá-de-cal na controvérsia, cuja observância, a rigor, somente se explica pelo mau hábito nacional de solver problemas jurídicos com uma consulta a todas as fontes normativas, exceto à Lei das Leis: efetivamente, quando se vê que à Advocacia-Geral da União, à Procuradoria-Geral da Fazenda Nacional e às Procuradorias dos Estados, Municípios e Distrito Federal incumbe (arts. 131 e 132 da CF de 1988), com exclusividade, a representação judicial das pessoas jurídicas de capacidade política, perde sentido tentar responder ao problema com as possíveis especificidades da Lei 1.533/1951, que contra a Lei Magna não prevalecerão. A solução constitucional é, pois, inequívoca: parte, também no mandado de segurança, é a pessoa jurídica de direito público a que vinculada a autoridade coatora. E essa pessoa jurídica só atua por meio dos representantes indicados nos arts. 131 e 132 da CF — o que torna obrigatória sua citação, independentemente da notificação do coator, para prestar informações" (Op. cit., p. 93-94). A comunicação da pessoa jurídica estava prevista na letra "a" do $\$ 1^{\circ}$ do art. $8^{\circ}$ da Lei $n^{\circ} 191 / 36$ e no inciso II do art. 322 do Código de Processo de 1939. Este último diploma utilizava melhor redação: mandava notificar o coator e citar o representante legal da pessoa jurídica de direito público (na verdade, quem é citada é a própria pessoa jurídica, não seu representante legal, este recebe a citação). No dizer expressivo de Sérgio Ferraz houve, pois, nesse tema "verdadeiro retrocesso técnico na Lei 1.533" (Op. cit., p. 90).

A\&C R. de Dir. Administrativo \& Constitucional, Belo Horizonte, ano 8, n. 33, p. 47-90, jul./set. 2008 
no prazo de dez dias; ${ }^{42}$ o Ministério Público atua como custos legis; ${ }^{43}$ a apelação é recebida apenas no efeito devolutivo, nos termos do art. 12, parágrafo único; ${ }^{44}$ a pessoa jurídica de direito público é intimada das decisões pessoalmente e não pelo diário oficial, nos termos do art. $3^{\circ}$ da Lei $n^{\circ}$ $4.348 / 64 .{ }^{45}$ Se o administrado optar pelo rito ordinário - e para tanto basta não utilizar na exordial o designativo "mandado de segurança" —, apesar de obter do Judiciário a mesma tutela - a tutela mandamental pode ser concedida no rito ordinário e pode sê-lo liminarmente pela antecipação da tutela —, o exame jurisdicional da antijuridicidade submeter-se-á a regime sensivelmente distinto: não haverá prazo decadencial para a propositura da ação judicial (pode haver prazo decadencial para a correção jurisdicional do ato, coisa completamente diferente); a autoridade responsável pela antijuridicidade não será notificada para apresentar informações; a pessoa jurídica de direito público será citada para apresentar contestação no prazo de 60 dias, nos termos do arts. 297 e 188 do Código de Processo Civil vigente; como regra geral, o Ministério Público não participa do processo, ressalvadas as hipóteses do art. 82 do CPC; ${ }^{46}$ em regra, a apelação tem efeito suspensivo. ${ }^{47}$

\footnotetext{
42 Por todos, menciona-se, mais uma vez, a doutrina de Sérgio Ferraz: "Por último, sendo o prazo das informações o único de natureza processual típico da Lei 1.533, impor-se-á sua observância (sem as ampliações do art. 188 do CPC, pois que estabelecido em lei especial) também para a contestação da pessoa jurídica de direito público" (Mandado de segurança, p. 94). Há quem afirme, em flagrante equívoco, que a contestação deve ser apresentada pela autoridade coatora. Por todos: MEIRELLES. Mandado de Segurança, p. 66-67. A comunidade jurídica não admite a incidência no rito do mandamus do art. 188 do CPC, cujo preceito confere à Administração Pública prazo em quádruplo para contestar.

${ }^{43}$ A oitiva do representante do Ministério Público é expressamente exigida pelo art. 10 da Lei n 1.533/51, independentemente do objeto do mandamus. É, hoje, indiscutível a natureza de sua atuação. Por todos: FERRAZ. Mandado de segurança, p. 296-304.

44 Diz Sérgio Ferraz: "A mandamentalidade da sentença concessiva afora os fins superiores do remédio, de proteção ao administrado contra os desbordamentos do poder, confluem para inadmitir efeito suspensivo nas sentenças concessivas de segurança" (Mandado de segurança, p. 327). Acompanham-no, dentre outros: Hely Lopes Meirelles (Mandado de segurança, p. 74) e Lúcia Valle Figueiredo (Mandado de segurança, p. 212-213). A ilustre publicista considera, ademais, inconstitucionais as leis que atribuem efeito suspensivo às sentenças proferidas no mandado de segurança (Op. cit., p. 213-217).

45 A Lei $n^{\circ} 10.910 / 2004$ alterou a redação do art. $3^{\circ}$ da Lei $n^{\circ} 4.348 / 64$ para determinar que os representantes judiciais da entidades federativas e de suas respectivas autarquias e fundações sejam intimados pessoalmente pelo juiz, no prazo de 48 horas, das decisões judiciais em que suas autoridades administrativas figurem como coatoras. A redação é clara: a intimação é pessoal.

${ }^{46}$ A comunidade jurídica brasileira entende que a mera presença da Administração Pública no litígio não faz com que o objeto da lide seja o interesse público e, pois, não importa na incidência do inciso III do art. 82 do CPC, vale dizer, na intervenção do Ministério Público. Assim, entende a jurisprudência, acompanhada da doutrina majoritária, que numa ação com rito ordinário de indenização por danos decorrentes do exercício da função pública ou numa ação declaratória de inexistência de relação jurídica tributária ou desconstitutiva do ato de lançamento tributário, o objeto não é o interesse público, mas o interesse privado, respectivamente, do administrado lesado e do administrado contribuinte. Nessas ações não há, pois, a intervenção do Ministério Público, salvo se configurado outro motivo legal, como, por exemplo, o autor ser absolutamente incapaz.

47 Essa regra decorre do art. 520 do Código de Processo: "A apelação será recebida em seu efeito devolutivo e suspensivo. Será, no entanto, recebida só no efeito devolutivo, quando interposta de sentença que: I homologar a divisão ou a demarcação; II - condenar à prestação de alimentos; III - revogado; IV - decidir o
} 
O regime da correção jurisdicional da antijuridicidade praticada no exercício da função pública, adotado o entendimento de que a Lei $\mathrm{n}^{\mathrm{o}} 1.533 / 51$ subsiste no mundo jurídico, fica subordinado à vontade do administrado. Em ambas as vias obtém-se igual tutela jurisdicional, a tutela mandamental, em ambas há possibilidade de antecipação da tutela, os efeitos proporcionados pelo rito ordinário e especial são, no caso, exatamente os mesmos. O regime processual, porém, é sensivelmente distinto, e a adoção de um ou outro regime depende da vontade do administrado, basta a escolha do rótulo: mandado de segurança ou ação de rito ordinário com pedido de antecipação de tutela. A incidência dos regimes depende da escolha do rótulo ditada pela vontade do administrado.

Essa solução, apesar de pacificamente adotada pela comunidade jurídica, é incorreta. A participação ou não do Ministério Público não é, por óbvio, ditada pelo interesse privado, mas pelo interesse público, não pode, pois, ficar condicionada à vontade do administrado. A defesa do ato impugnado também não diz respeito ao interesse privado: estabelecer o prazo de sessenta ou de dez dias para a contestação da Fazenda, se ela será ou não intimada pessoalmente, a depender da livre escolha do administrado em escolher o rótulo da ação, também não faz sentido, a defesa do ato é ditada pelo interesse público. Do mesmo modo, exigir ou não as informações da autoridade responsável pela edição do ato ou pela conduta impugnada, a depender da livre escolha do rito pelo autor da ação, é absurdo. De duas, uma: ou a função pública atendeu ao sistema normativo, ao interesse público, ou contrariou o sistema normativo, foi contrária ao interesse público. O exame da juridicidade da função pública não diz respeito apenas ao interesse privado do beneficiado ou prejudicado. A função pública, por definição, concretiza o interesse público e, por isso, o regime de seu controle não pode ficar subordinado à vontade do particular.

Um exemplo é suficiente para demonstrar o acerto do raciocínio. A cobrança de tributos é ditada pelo interesse público, a dimensão pública do interesse privado ${ }^{48}$ exige a cobrança, a arrecadação, assim, interessa a toda coletividade. O exame da juridicidade do ato de lançamento tributário, portanto, é de interesse de todos. O magistrado, antes de dizer se o ato é

processo cautelar; V - rejeitar liminarmente embargos à execução ou julgá-los improcedentes; VI - julgar procedente o pedido de instituição de arbitragem; VII - confirmar a antecipação dos efeitos da tutela". O inciso VII, acrescentado pela Lei n 10.352/2001, não há como negar, importou numa aproximação do rito ordinário com o rito do mandado de segurança.

${ }^{48}$ A expressão é de Celso Antônio Bandeira de Mello (Curso de direito administrativo, cap. I-33, p. 57). 
válido ou inválido, deve permitir que a Fazenda se manifeste, deve ouvir a autoridade responsável, deve ouvir o Ministério Público. E isso não porque o interesse privado exige, mas em decorrência do interesse público.

Enfim: o regime do exame jurisdicional da juridicidade da função pública é ditado pelo interesse público, não pelo interesse privado e, por isso, não pode ficar condicionado à livre escolha do administrado. A partir do momento em que a tutela mandamental e antecipação dessa tutela foram estendidas ao rito ordinário, desapareceu o rito especial. Houve, de fato, a retirada do mundo jurídico da Lei $\mathrm{n}^{\circ} 1.533 / 51 \mathrm{e}$, por conseguinte, inexiste duplicidade de ritos, ordinário e especial, para o exame da juridicidade da função pública. Contudo, é imperioso perceber que o rito ordinário, quando tem por objeto o exame da função pública, de certa forma especializa-se, torna-se um rito especial. A compreensão dessa assertiva é o último passo deste estudo.

\section{Regime jurídico do controle jurisdicional da função pública}

O direito processual civil foi construído sob a ótica do direito privado, tendo em vista a solução de conflitos entre particulares. ${ }^{49}$ Os institutos processuais não foram pensados para o direito público, para as relações jurídicas em que o Estado se faz presente. Vivencia-se, por isso, um lento processo de construção de um direito processual voltado para o direito público. ${ }^{50}$ O jurista, diante de relações de direito público, deve ter atenção redobrada ao interpretar as leis processuais: comumente a solução correta não está

\footnotetext{
49 Registre-se a percuciente observação de Ovídio A. Baptista da Silva: "Nossa submissão à actio romana e ao correspondente procedimento ordinário, fundamentalmente um reflexo do privatismo a que ficou reduzida a jurisdição, transformada em assunto entre credores e devedores, impede o resgate da categoria dos deveres, cuja recuperação se mostra tão urgente em nosso sistema que, apesar da cultura privatística, ainda apresenta traços saudáveis de sua vocação para o direito público, especialmente agora que a buscada constitucionalização do Direito Processual Civil tornou-se tema da moda". Processo e ideologia, p. 200.

50 Nesse sentido, vêm a lume as considerações do aclamado Prof. Arruda Alvim: "Do ponto de vista da colocação do Processo Civil, no sistema jurídico, era essa disciplina encarada como um apêndice do Direito Civil, fundamentalmente realizando unicamente o Direito subjetivo e comungando de grande parte dos princípios que informavam o Direito Privado, quais fossem a disponibilidade dos direitos, a idéia de que a Justiça seria realizável exclusivamente pela atividade das partes - e sem interferência sensível do Judiciário, no curso do procedimento (em especial, no que diz respeito à não interferência do juiz na atividade probatória, na coartação de conduta antiética da parte, etc.) — com o que se tinha, correlatamente, um Poder Judiciário eminentemente inerte, mesmo depois de instaurado um processo e durante o seu evolver. A evolução porque passou o Processo Civil, enquanto disciplina e direito positivo, foi a de se vir a entendê-lo como matéria autônoma do Direito Privado, e, conseqüentemente, tudo o que respeitasse ao processo, veio a ser entendido e disciplinado positivamente como matéria de Direito Público". Tratado de direito processual civil, v. 1, p. 106. O próprio nome indica que a construção do direito processual "civil" deu-se a partir do direito civil e não do direito administrativo: os institutos processuais foram inicialmente pensados para um conflito individual entre particulares. Não foram pensados para conflitos coletivos nem para conflitos em que seja parte o Poder Público. A doutrina já efetuou a construção de uma teoria do processo coletivo, mas ainda é incipiente a construção de uma teoria do processo voltada para as particularidades da relação jurídica de direito público.
}

A\&C R. de Dir. Administrativo \& Constitucional, Belo Horizonte, ano 8, n. 33, p. 47-90, jul./set. 2008 
no plano da literalidade. Devem-se distinguir as ações que têm por objeto relações de direito privado das ações que têm por objeto relação de direito público. Pode-se afirmar que o rito ordinário das últimas é um rito especial, há um conjunto de regras implícitas no Código de Processo ditado pelo regime de direito público próprio do controle da função pública.

\subsection{Apelação da Administração Pública e efeito suspensivo}

Para entender esse regime, faz-se necessário retomar algumas noções fundamentais. ${ }^{51}$ A primeira delas é o papel do Poder Judiciário no sistema normativo: ele é o oráculo do Direito. ${ }^{52}$ A expressão é muito apropriada para indicar a principal função atribuída ao Poder Judiciário: a ele incumbe dizer a última palavra sobre o Direito. Tanto a decisão jurisdicional definitiva como a provisória são manifestações do oráculo do Direito, só que a segunda é passível de ser modificada pelo próprio Poder Judiciário. Eis a natureza de uma sentença ou de um acórdão sub judice: eles são manifestação da autoridade qualificada pelo sistema como apta a ser a porta-voz da vontade do sistema normativo, da resposta juridicamente correta. ${ }^{53}$

Fixada essa premissa, impende assentar algumas noções elementares sobre a Administração Pública, infelizmente desprezadas por muitos. $\mathrm{O}$ Estado é uma realidade instrumental: ele existe para realizar o bem comum ou, em termos mais concretos, para cumprir o Direito, para concretizar na medida exigida pelo sistema normativo os princípios constitucionais. ${ }^{54}$ A função administrativa, como toda função estatal, possui esse desiderato: o

\footnotetext{
51 Sobre as considerações que seguem, vide nosso: Prescrição da pretensão tributária. Revista Tributária e de Finanças Públicas, p. 220-223.

52 A expressão é de Celso Antônio Bandeira de Mello. Afirma o nobre jurista: "Portanto, o órgão jurisdicional, ao decidir, afirma que o direito por ele pronunciado preexiste e que a solução dada é a cabível e é a única, com exclusão de qualquer outra, porque fala em nome do que já está solucionado na lei, da qual ele é o porta-voz no caso concreto. O deslinde pode (ou não) ser difícil; pode demandar recurso a princípios gerais, mas, de direito, sua pronúncia é a expressão oracular do que as normas aplicáveis 'querem' naquele caso". Mandado de segurança contra denegação ou concessão de liminar. Revista de Direito Público, p. 58. E, noutra oportunidade, afirmou: "O juiz é o oráculo do direito no caso concreto. É esta a função do juiz. Quando o juiz decide num sentido, aquela decisão que ele toma é para aquele instante, a verdade legal, e é produzida a título de dizer: a verdade legal, a única que existe porque duas não podem existir conflitantes numa mesma situação". Juízo liminar, poder-dever de exercício do poder cautelar nessa matéria. Revista Trimestral de Direito Público, p. 114.

53 Por óbvio, a autoridade judicial, como todo ser humano, é passível de erro e muitas vezes erra grosseiramente: não acolhe a solução juridicamente correta. Não se adota a doutrina kelseniana segundo a qual um dispositivo é constitucional se o órgão competente diz sê-lo. Há no sistema uma regra de calibração que atribui validade aos erros do Judiciário. FERRAZ JR. Teoria da norma jurídica, p. 131 et seq. Isso não significa que por força desse erro a incompatibilidade desapareça: tanto ela permanece que o próprio STF ao examinar um novo RE ou uma nova ADin pode reconsiderar sua decisão e considerar constitucional a norma dantes declarada por ele inconstitucional. Deveras, pela regra de calibração a decisão jurisdicional equivocada é válida; não deixa de ser, apesar disso, passível de ser criticada pelo cientista do Direito.

54 Sobre o tema, vide nosso: Efeitos dos vícios do ato administrativo, p. 33 et seq.
} 
fiel cumprimento do Direito. Por isso, diante das manifestações do Poder Judiciário, oráculo do Direito, particulares e Administração Pública não se equiparam. O Direito assegura aos primeiros a busca de seus interesses egoísticos, a busca da máxima concretização dos princípios jurídicos favoráveis a sua esfera jurídica; o direito exige da segunda a busca do interesse público primário, a busca da concretização dos princípios incidentes na exata medida exigida pelo ordenamento jurídico. O acatamento da manifestação jurisdicional só é imposto ao administrado quando expressamente exigido pelo sistema; já o acatamento pela Administração independe de previsão expressa, é uma decorrência lógica de sua natureza, de seu papel.

Fixadas essas duas premissas, é possível apresentar a primeira peculiaridade do rito das ações que têm por objeto o exame do exercício da função pública. Por força do art. 520 do CPC, como regra geral, a apelação é recebida no efeito devolutivo e no efeito suspensivo. Segundo o entendimento assente, as exceções a essa regra geral são expressas. Eis a conclusão proposta: ainda que a apelação da Administração Pública tenha sido recebida no efeito suspensivo, ela não terá o condão de suspender os efeitos da sentença. Ao particular interessa o descumprimento da decisão jurisdicional sub judice, e o sistema jurídico reconhece esse interesse; à Administração Pública, do ponto de vista exclusivamente jurídico, não interessa esse descumprimento. O efeito suspensivo do apelo é uma regra que concretiza o interesse do vencido de só ser constrangido a aceitar a decisão jurisdicional após seu reexame. É uma regra aplicável apenas aos administrados.

Evidente que, se Administração estiver convencida do desacerto da decisão jurisdicional, poderá obter a suspensão dos seus efeitos mediante requerimento ao relator da apelação ou mediante propositura de ação cautelar. ${ }^{55}$ Deveras: a suspensão dos efeitos da sentença só pode ser obtida pela Administração Pública mediante decisão jurisdicional autônoma, de natureza cautelatória, que tenha por conteúdo essa suspensão; jamais decorrerá automaticamente da mera interposição do recurso. ${ }^{56}$ Eis a

\footnotetext{
55 Aplica-se, portanto, à sentença proferida em face da Fazenda Pública o regime assentado para os acórdãos. Perceba-se que todos os recursos interpostos contra a decisão proferida em segunda instância não são dotados de efeito suspensivo. Para atribuir efeito suspensivo ao recurso especial ou ao recurso extraordinário, faz-se necessária a propositura de ação cautelar. Sobre o tema, existem duas Súmulas do STF: 634 — "Não compete ao Supremo Tribunal Federal conceder medida cautelar para dar efeito suspensivo a recurso extraordinário que ainda não foi objeto de juízo de admissibilidade na origem"; 635 — "Cabe ao Presidente do Tribunal de origem decidir o pedido de medida cautelar em recurso extraordinário ainda pendente do seu juízo de admissibilidade". Assim: até a prolação do juízo de admissibilidade, a cautelar deve ser proposta no juízo de origem; após o exame, a cautelar deve ser proposta no juízo ad quem. Nos casos em que o recorrente for a Fazenda, essa regra aplica-se a todas as decisões, incluídas as de primeira instância.

${ }^{56}$ A mera afirmação do magistrado de que "recebe o apelo em ambos os efeitos" não tem o condão de
}

A\&C R. de Dir. Administrativo \& Constitucional, Belo Horizonte, ano 8, n. 33, p. 47-90, jul./set. 2008 
primeira conclusão: a regra do art. 12, parágrafo único, da revogada Lei no $1.533 / 51$, pela qual a apelação da decisão que concede a tutela mandamental em face da Fazenda Pública é recebida apenas no efeito devolutivo, é por interpretação sistemática, considerada implícita no sistema e se aplica a todas as ações movidas em face da Administração Pública.

\subsection{Participação do Ministério Público}

Defende-se aqui, ${ }^{57} \mathrm{em}$ dissonância com a doutrina e jurisprudência cristalizadas, a necessidade de participação do Ministério Público, como custos legis, em todas as ações judiciais que tenham por objeto o exame da função pública. O artigo 82, III, do CPC, exige a intervenção do Ministério Público em todas as "causas em que há interesse público evidenciado pela natureza da lide ou qualidade da parte". Em todas as ações movidas em face da Administração Púbica há interesse público pela natureza da lide ou qualidade da parte, pois, por definição, a atuação da Administração Pública deve consistir, sempre, na concretização do interesse público.

A tese deve ser enfrentada com desvelo, já que vai contra entendimento pacificado. Tudo gira em torno da exegese de quatro dispositivos constitucionais: o caput do art. 127 e os incisos II, III e IX do art. 129. Estabelece expressamente o caput do artigo 127 que incumbe ao parquet a "defesa da ordem jurídica" e dos "interesses sociais e individuais indisponíveis”. A primeira expressão já fundamenta a participação do Ministério Público: nas ações referidas afirma-se que o exercício da função pública violou o Direito, quer dizer, que houve contrariedade à ordem jurídica. Perceba-se: se o Judiciário considerar ilegal ou inconstitucional a atuação pública legal e constitucional, ou se deixar de considerar ilegal ou inconstitucional a atuação pública ilegal ou inconstitucional, haverá violação da ordem jurídica. Enfim: a proteção da ordem jurídica exige que o Ministério Público atue nessas ações como fiscal da lei (entenda-se, como fiscal do ordenamento jurídico).

A segunda expressão mencionada reforça esse entendimento. Primeiramente, não há diferença conceitual significativa entre o interesse social e o interesse público, todo interesse público é também um interesse social e vice-versa: interesse público é o resultado da ponderação das circunstâncias

suspender os efeitos da sentença para a Administração Pública, pois o efeito suspensivo do apelo não se aplica ao Poder Público. Para que haja essa suspensão, é necessário o proferimento de decisão cautelar, devidamente fundamentada.

57 Retomamos aqui o que defendemos em nosso: Efeitos dos vícios do ato administrativo, p. 522-528.

A\&C R. de Dir. Administrativo \& Constitucional, Belo Horizonte, ano 8, n. 33, p. 47-90, jul./set. 2008 
fáticas e jurídicas, é a medida de concretização, revelada pela ponderação efetuada, dos princípios constitucionais incidentes ${ }^{58}$ Assim, como todo exercício de função pública ilegal ou inconstitucional contraria o interesse público e, conseqüentemente, o interesse social, impõe-se, por mais essa razão, a atuação do Ministério Público em todas as ações movidas em face da Administração Pública.

Não obstante, o signo "indisponível" parece ser a causa do nãoacolhimento da tese ora defendida. O interesse público ou social é, por definição, indisponível. Se se pudesse personalizar o ordenamento jurídico, poder-se-ia dizer que, diante de cada situação, o ordenamento tem uma "vontade", qual seja, a concretização, em determinada medida, de um ou mais princípios constitucionais, medida essa revelada pela ponderação de todas as normas incidentes. Pois bem, a ninguém é dado dispor dessa "vontade", isso pelo simples fato de que ela não é de ninguém, ela pertence ao ordenamento jurídico. Assim, interesse social é, por definição, indisponível. Ao constar do art. 127, portanto, essa palavra só pode se referir ao interesse individual. Nesses termos, pelo que se expôs até aqui, ao Ministério Público compete a defesa do interesse público e do interesse individual indisponível. ${ }^{59}$

Necessário, pois, examinar a relação entre o interesse público e o interesse individual. Os direitos individuais positivados no texto constitucional são princípios incidentes que devem ser considerados nas ponderações efetuadas e, por isso, o interesse público muitas vezes consiste na concretização de interesses individuais. $\mathrm{O}$ conceito adotado não deixa dúvida de que o interesse público pode ser coincidente com o interesse individual, pois é de interesse da coletividade a observância dos direitos individuais ${ }^{60}$ Interesse público é cumprimento da Constituição, é

\footnotetext{
${ }^{58} \mathrm{O}$ conceito adotado não contraria o enunciado por Celso Antônio Bandeira de Mello, cuja repetição nunca é inoportuna: "É que, na verdade, o interesse público, o interesse do todo, do conjunto social, nada mais é que a dimensão pública dos interesses individuais, ou seja, dos interesses de cada indivíduo enquanto partícipe da Sociedade (entificada juridicamente no Estado)" (Curso de direito administrativo, I-34, p. 57). E mais adiante: "Donde, o interesse público deve ser conceituado como o interesse resultante do conjunto dos interesses que os indivíduos pessoalmente têm quando considerados em sua qualidade de membros da Sociedade e pelo simples fato de o serem" (Idem, cap. I-36, p. 58). Interesse público e interesse social, também para o magno jurista, são, ao menos, conceitos muito próximos.

59 Hugo Nigro Mazzilli, talvez o que mais tenha se dedicado ao estudo do Ministério Público brasileiro, robora o afirmado: "A indisponibilidade do interesse, embora não esgote as hipóteses de atuação do Ministério Público, está presente na maior parte delas. Em suas atividades institucionais, o Ministério Público sempre busca um interesse público - mais propriamente o interesse público primário, a que já nos vimos referindo". Regime jurídico do Ministério Público, p. 78.

60 Reitera-se a absoluta imprescindibilidade da leitura de Celso Antônio Bandeira de Mello sobre o tema (Curso de direito administrativo, I-31-49, p. 56-66). A sociedade tem interesse na cobrança dos tributos, mas
} 
concretização dos princípios constitucionais, mas na "medida exata" revelada pela ponderação de todos os princípios e regras incidentes.

Cumpre perceber que o interesse público pode ser coincidente com interesse individual disponível ou indisponível. Se uma pessoa é acometida de grave enfermidade que coloque sua vida em risco, a incidência do princípio de proteção da vida e da saúde das pessoas exige que o Estado lhe preste, ainda que gratuitamente, cuidados médicos. Trata-se de interesse público coincidente com o interesse individual indisponível da pessoa doente. Se o Estado cobra de uma pessoa tributo não instituído em lei, o princípio da estrita legalidade tributária exige que a cobrança seja afastada. O interesse público é coincidente com o interesse individual disponível da pessoa contribuinte. Em suma, sendo o interesse público a concretização máxima do princípio constitucional incidente, tendo em vista todas as demais normas jurídicas também incidentes, ele pode ser coincidente tanto com o interesse individual indisponível como com o interesse individual disponível.

Pacificou-se na doutrina e na jurisprudência, sem exceção conhecida, que não compete ao Ministério Público proteger o interesse público se ele for coincidente com o interesse individual disponível. ${ }^{61}$ Sem desprestigiar o entendimento de todos que adotam essa posição, trata-se de grande equívoco. Uma coisa é a vontade constitucional, outra coisa, completamente diferente, é a vontade individual: ainda que ambas sejam coincidentes, a primeira, ao contrário da segunda, será sempre indisponível. Explica-se: há um interesse público e indisponível em não cobrar tributos inconstitucionais, ainda que haja disposição do interesse individual em não pagar

\footnotetext{
também tem interesse no respeito à propriedade individual; é equivocado supor que o interesse social restrinja-se aos interesses da coletividade, em antagonismo ao interesse individual. Para que fique claro: o interesse social não se identifica com o individual, pois o indivíduo tem interesse em não pagar tributo, mas a sociedade necessita que os tributos sejam pagos; o indivíduo tem interesse em não ser desapropriado, mas a sociedade necessita da desapropriação. Porém, essa diferenciação é relativa, primeiro pelo óbvio fato de que o indivíduo tem interesse de que haja cobrança de tributos e desapropriações, segundo porque o interesse público exige o pagamento da justa indenização, impede que o tributo se transforme em confisco. A diferença está em que o interesse individual não se compromete com a ponderação de todos os princípios incidentes no caso, busca a máxima realização dos princípios que beneficiem a esfera do respectivo indivíduo. O interesse público ou social busca a máxima realização de todos os princípios incidentes, até mesmo dos princípios que beneficiem a esfera individual. Se o interesse individual consiste na máxima realização de P1, por exemplo, o interesse público ou social consiste na máxima realização de P1, P2, P3.

61 Para ilustrar esse entendimento, menciona-se famosa decisão do C. STF: "O Ministério Público não tem legitimidade para aforar ação civil pública para o fim de impugnar a cobrança de tributos ou para pleitear a sua restituição. É que, tratando-se de tributos, não há, entre o sujeito ativo (poder público) e o sujeito passivo (contribuinte) relação de consumo, nem seria possível identificar o direito do contribuinte com 'interesses sociais e individuais indisponíveis'". BRASIL, Supremo Tribunal Federal. 2 ${ }^{\mathrm{a}}$ T. RE n 248.191-AgR/ SP, Rel. Min. Carlos Velloso, j. 01.10.2002, v.u., DJ, p. 64, 25 out. 2002.
} 
tributos inconstitucionais. Enfim: ao Ministério Público compete tutelar a ordem pública e os interesses sociais, ainda que assim o fazendo tutele também interesses individuais disponíveis. ${ }^{62}$

Os incisos II e III do art. 129 reforçam esse entendimento. Pelo inciso II o Ministério Público deve zelar para que os Poderes Públicos respeitem os direitos assegurados na Constituição. A atuação antijurídica da Administração Pública sempre consiste num desrespeito à ordem constitucional. Ainda que haja mera desconformidade com uma regra legal, haverá violação do princípio da legalidade e, conseqüentemente, desobediência à vinculação à ponderação legislativa, entenda-se, ao princípio democrático. Pelo inciso III o Ministério Público deve zelar pelo respeito de todos os interesses difusos. Não há como negar, ainda que muitos se esforcem nesse sentido, a existência de um interesse difuso ao bom cumprimento da função pública. Todo cidadão tem interesse na fiel observância do Direito pela Administração, e tal interesse, sendo indivisível e indeterminável, é, por óbvio, um interesse difuso.

Finalmente, algumas considerações sobre o inciso IX do art. 129 são de grande utilidade para correta compreensão do tema. A Constituição veda ao Ministério Público a "representação judicial" e a "consultoria jurídica das entidades públicas”, essas funções devem ser exercidas pelas respectivas Procuradorias, nos termos dos artigos 131 e 132. Por força dessa diferenciação funcional muitos supõem, em infeliz equívoco, que ao Ministério Público compete a defesa do interesse público primário e às Procuradorias a defesa do interesse público secundário; ${ }^{63}$ e que, quando o interesse público primário e secundário são coincidentes, é vedada a

\footnotetext{
62 Dignas de nota as palavras de Hugo Nigro Mazzilli: "Já está superada, pois, a época em que procurávamos dar um enfoque não apenas prioritário, mas exclusivo, ao zelo do interesse indisponível por parte do Ministério Público. Vemos hoje que não se pode centrar, exclusivamente, a destinação institucional do Ministério Público na defesa de interesses indisponíveis. É certo que, se houver alguma característica de indisponibilidade parcial ou absoluta de um interesse, o Ministério Público deverá agir na esfera dessa indisponibilidade. Contudo, também pode ocorrer, e não raro ocorre, que a defesa de qualquer interesse, disponível ou não, convenha à coletividade como um todo, hipótese em que se justificará a atuação judicial ou extrajudicial do Ministério Público, na defesa do bem geral (interesse público primário)" (Regime jurídico do Ministério Público, p. 79-80). ${ }^{61}$ Para ilustrar esse entendimento, menciona-se famosa decisão do C. STF: "O Ministério Público não tem legitimidade para aforar ação civil pública para o fim de impugnar a cobrança de tributos ou para pleitear a sua restituição. É que, tratando-se de tributos, não há, entre o sujeito ativo (poder público) e o sujeito passivo (contribuinte) relação de consumo, nem seria possível identificar o direito do contribuinte com 'interesses sociais e individuais indisponíveis'”. BRASIL, Supremo Tribunal Federal. $2^{\mathrm{a}}$ T. RE n 248.191-AgR/SP, Rel. Min. Carlos Velloso, j. 01.10.2002, v.u., DJ, p. 64, 25 out. 2002.

${ }^{63}$ Afirma Hugo Nigro Mazzilli: "Há total incompatibilidade do exercício da advocacia pelos membros do Ministério Público, ainda que tal advocacia se exerça em prol de interesses da própria Fazenda Pública. Afinal, como ficaria o procurador-geral da República, para opinar ou para recorrer, quando de um conflito entre o interesse público primário e secundário na clássica distinção de Renato Alessi, já referida? Suponhamos que, numa decisão de que só coubesse recurso seu, quando estivesse a União a defender interesse público
}

A\&C R. de Dir. Administrativo \& Constitucional, Belo Horizonte, ano 8, n. 33, p. 47-90, jul./set. 2008 
atuação do MP. Em relação ao controle do exercício da função pública, ${ }^{64}$ porém, a função do Ministério Público e a das Procuradorias muito se aproximam: ambos existem para garantir o cumprimento do interesse público, que por definição restringe-se ao primário, quer dizer, ambos existem para que o exercício da função pública não contrarie o Direito. A Constituição dá grande relevância ao princípio da conformidade da função pública ao Direito, tanto que exige a instituição de dois órgãos: primeiro, a Procuradoria, cuja função não é defender o interesse secundário, mas defender o interesse público, seu papel é zelar para que a entidade pública respeite o Direito ${ }^{65}$ segundo, o Ministério Público, cuja função é subsidiária, havendo falha da Procuradoria, quer dizer, se for cometida antijuridicidade, ele deve impugná-la administrativa ou judicialmente.

É fundamental ter presente que no tema do controle da função pública ambas as instituições, Procuradorias e Ministério Público, possuem o mesmo desiderato: o cumprimento do interesse público (pleonasticamente qualificado como primário). O MP, porém, nesse campo possui atuação subsidiária, de controle, atua na falha da Procuradoria.

Por tudo isso, fixa-se a segunda conclusão: a regra do art. 10 da revogada Lei ${ }^{\circ} 1.533 / 51$, pela qual o Ministério Público deve ser ouvido em todas as ações mandamentais propostas em face da Fazenda Pública, é por interpretação sistemática, considerada expressa no art. 82, III, parte final, do CPC, e se aplica a todas as ações em que a Administração Pública seja parte.

\subsection{Prerrogativas da Fazenda Pública}

As chamadas prerrogativas da Fazenda Pública em juízo decorrem de vários fatores. Primeiro: nenhum escritório de advocacia, por maior que

secundário (visto do ângulo da administração, o que nem sempre se confunde com o interesse do bem comum, do que temos fartos exemplos), com a defesa de que interesse ficaria o defensor de ambos?! E nos casos em que devesse dar um parecer: estaria opinando como advogado da Fazenda ou como defensor da coletividade?!" (Regime jurídico do Ministério Público, p. 251). É assaz importante não perder de mira a advertência de Celso Antônio Bandeira de Mello no sentido de que "os interesses secundários do Estado só podem ser por ele buscados quando coincidentes com os interesses primários, isto é, com os interesses públicos propriamente ditos" (2007, I-45, p. 63). Quer dizer: a União simplesmente não tem competência para defender os interesses secundários aludidos por Mazzilli.

${ }^{64}$ A competência do MP é mais ampla: ele é o dominus litis da ação penal pública, é encarregado da defesa dos interesses indígenas, etc.

65 José Afonso da Silva também reconheceu o verdadeiro papel da Advocacia Pública: "A Advocacia Pública assume, no Estado Democrático de Direito, mais do que uma função jurídica de defesa dos interesses patrimoniais da Fazenda Pública, mais até mesmo do que a defesa do princípio da legalidade, porque lhe incumbe igualmente e veementemente a defesa da moralidade pública". A Advocacia Pública e Estado Democrático de Direito. Revista de Direito Administrativo, p. 284. 
seja, tem o volume de trabalho da Procuradoria. A Administração Pública se relaciona com toda coletividade e, por decorrência lógica, é parte num número de ações judiciais significativamente maior do que qualquer pessoa de direito privado. Por definição, a Administração Pública pretende cumprir corretamente sua função, pretende sempre atender da melhor forma possível ao Direito; logo, ela é a primeira interessada na correção das antijuridicidades cometidas pelos agentes públicos. Por isso, a Administração só deve litigar em juízo quando estiver convicta de que a pretensão do administrado não é agasalhada pelo Direito; se a Administração Pública não acreditar na juridicidade de sua tese defensiva, ela não deve litigar, deve corrigir a ilicitude administrativa. ${ }^{66}$ Essa diretriz, infelizmente, é desprezada pelo Poder Público. As Procuradorias não compreendem seu papel, defendem toda conduta da Administração, como se esta tivesse interesse jurídico nessa defesa. Só o tempo, o aprimoramento do Estado de Direito e a melhor compreensão dos institutos jurídicos mudarão esse quadro. Sem embargo, não há como negar: é impossível comparar a atuação processual da Procuradoria com a atuação processual da Advocacia privada. Na advocacia pública não há um acompanhamento individualizado dos processos; o grande volume de ações, em especial nos grandes centros urbanos, exige uma atuação generalizada. ${ }^{67}$

Ademais, além de atuar num volume muito maior de processos, a Fazenda Pública encontra um obstáculo não encontrado no setor privado. A máquina administrativa é, sempre, mais complexa. São vários órgãos, vários agentes e uma longa linha hierárquica. Numa empresa privada, a consulta a um departamento é efetuada em poucos minutos. Na Administração, faz-se necessário encaminhar ofício, este passa por diversos agentes. Basta pensar num fato ocorrido numa escola municipal: o tempo gasto para obtenção pelo Departamento Jurídico do Município, encarregado

\footnotetext{
${ }^{66}$ Em assonância com essa assertiva afirma Celso Antônio Bandeira de Mello: "Com efeito, nada obstante seja comum a resistência administrativa em cumprir suas obrigações, quando o fazê-lo implica reconhecer injuridicidade prévia de sua conduta, dita resistência - que resulta em forçar o lesado a recorrer às vias judiciais - não é procedimento juridicamente plausível. Muito pelo contrário. Este equívoco, não raro corrente, liga-se a uma errônea compreensão da verdadeira missão do Estado. Seu primeiro dever é o de obedecer à ordem jurídica. É o de cumpri-la; de lhe dar atendimento. Daí que não lhe calha resistir a pretensões jurídicas alheias fundadas". Direito a férias anuais. Revista de Direito Público, p. 160.

$67 \mathrm{Na}$ advocacia privada é muito incomum que o advogado não saiba, a todo tempo, o estado atual de cada feito em que atua. Na advocacia pública da cidade de São Paulo, por exemplo, esse acompanhamento individualizado é, muitas vezes, impossível. O Procurador atua em milhares de ações, cumpre os prazos e manifesta-se nos autos à medida que estes chegam à Procuradoria. Durante um processo é comum atuarem dez, doze procuradores diferentes. Donde: é impossível um acompanhamento individualizado. O fenômeno reflete bem o que o insigne jusfilósofo Tércio Sampaio Ferraz Jr. chama de redução do direito a um "objeto de consumo". Introdução ao estudo do direito, p. 28.
}

A\&C R. de Dir. Administrativo \& Constitucional, Belo Horizonte, ano 8, n. 33, p. 47-90, jul./set. 2008 
da defesa judicial, das informações dos agentes que participaram dos fatos é significativo. A extensão, a complexidade da máquina administrativa e sua estrutura hierárquica são fatores que muito dificultam a defesa em juízo e não podem ser desprezados pelo sistema normativo.

Finalmente, a defesa do particular interessa ao particular, a defesa da Fazenda Pública interessa a toda coletividade. Nos termos dantes expostos, se a função pública pressupõe sempre o interesse público e este interessa a toda coletividade, seja ou não coincidente com o interesse privado, a defesa da função pública também interessa a todos. Coerentemente, pela revelia da Fazenda Pública não se reputam verdadeiros os fatos alegados pelo autor, pois o interesse público é, por definição, indisponível (CPC, art. 320, II). Perceba-se: diante da indisponibilidade do interesse público, a revelia da Fazenda simplesmente não gera efeitos jurídicos processuais. Se a defesa for apresentada após o prazo, não gerará nenhum efeito processual, o juiz não pode mandar desentranhá-la ou desconsiderar o nela afirmado quando da prolação da sentença.

Por causa desses três fatores - o volume de processos em que é parte, a complexidade da máquina administrativa e a natureza dos interesses que defende - a Fazenda Pública difere, enquanto parte no processo judicial, do administrado. O princípio da isonomia importa em tratar desigualmente os desiguais: os interesses devem ser discriminados desde que haja uma correlação lógica entre o fator erigido em critério de discrímen e a desequiparação pretendida. ${ }^{68}$ É, pois, inegável que as peculiaridades da Fazenda Pública justificam certas prerrogativas processuais. A primeira prerrogativa, prevista no art. 188 do CPC, não gera controvérsias: prazo em quádruplo para contestar e em dobro para recorrer. Caso essa regra fosse revogada, ainda assim, o prazo não seria o mesmo que o fixado para os particulares. O prazo idêntico ou menor é inconstitucional por flagrante violação dos princípios da isonomia e da supremacia do interesse público sobre o privado, ${ }^{69}$ pois, além de tratar igualmente os desiguais, ele dificulta

\footnotetext{
68 É a clássica lição de Celso Antônio Bandeira de Mello. Conteúdo jurídico do princípio da igualdade. 3. ed. 4. tiragem. São Paulo: Malheiros, 1997. p. 38. Sobre a relação entre o princípio da igualdade e as prerrogativas processuais da Fazenda Pública, vide: MORAES. As prerrogativas e o interesse da Fazenda Pública. In: SUNDFELD; BUENO (Coord.). Direito processual público, p. 66-78.

69 O ordenamento jurídico estabelece uma razão prima facie em favor do interesse da coletividade. Assim, na ponderação entre o interesse de um particular e o interesse da coletividade há, em abstrato, um peso maior dado ao interesse da coletividade. Disso não decorre que sempre o interesse da coletividade irá prevalecer. Nenhum princípio tem caráter absoluto, mas isso não quer dizer que todos os princípios tenham, num plano abstrato, a mesma importância, o mesmo peso; abstratamente considerados, os princípios apresentam pesos diferentes. Eis a função do princípio da supremacia do interesse público sobre o privado: ele introduz
} 
ou impossibilita a tutela do interesse público. Assim, em todas as ações a Fazenda Pública, independentemente do rito, tem prazo em quádruplo para contestar e em dobro para recorrer.

A segunda prerrogativa é bem mais problemática. A intimação da Fazenda pelo diário oficial muito dificulta e, muitas vezes, inviabiliza sua defesa. No Agravo de Instrumento 439.613-SP, relatado pelo Ministro Celso de Mello, discutiu-se o tema da intimação do Procurador Municipal: o Município suscitou nulidade porque o Procurador que atuava no feito não havia sido intimado de certa decisão. Decidiu o C. STF: para que a intimação seja válida basta a indicação do Órgão.$^{70}$ Essa decisão foi um

uma carga de argumentação em favor dos princípios relativos a bens coletivos. Ainda que, em teoria, haja alguém que contrarie essa "carga", na prática, porém, ela é tranqüilamente aceita por todos; negá-la é atentar contra o bom senso. Note-se que para Robert Alexy há uma precedência geral prima facie em favor dos direitos individuais e, por isso, num plano abstrato eles são mais pesados do que os bens coletivos (El concepto y la validez del derecho, p. 207). Muitos juristas brasileiros, sensivelmente influenciados pelo pensamento do jusfilósofo alemão, não perceberam o equívoco. Este decorreu, talvez, das profundas marcas deixadas no povo alemão pelo nazismo. Com efeito: os notáveis juristas que participaram da discussão até o momento não perceberam a ambigüidade na utilização da expressão "interesse público". Este não é um princípio jurídico, é o interesse a ser defendido pelo Estado, refere-se ao resultado da ponderação efetuada pelo agente público, ou seja, é o princípio cuja concretização é exigida pelo ordenamento jurídico. Assim, é incorreto falar em "princípio do interesse público". Não, porém, em "princípio da supremacia do interesse público sobre o privado", cuja compreensão exige notar a referida ambigüidade na utilização da expressão: isoladamente considerada, consiste no resultado da ponderação efetuada pelo agente público, ou seja, é o princípio que deve, segundo o ordenamento jurídico, ser concretizado; no princípio da supremacia, interesse público refere-se ao interesse da coletividade em oposição ao interesse do indivíduo. O ordenamento jurídico estabelece uma razão prima facie em favor do interesse da coletividade. Assim, sempre que se ponderar um interesse de um particular e o interesse da coletividade há, em abstrato, um peso maior dado ao interesse da coletividade. Disso não decorre que sempre o interesse da coletividade irá prevalecer. A conclusão oposta evidencia um desconhecimento da teoria de Alexy: nenhum princípio tem caráter absoluto, mas isso não quer dizer que todos os princípios tenham, num plano abstrato, a mesma importância, o mesmo peso; abstratamente considerados, os princípios apresentam pesos diferentes. Diz Alexy: "El carácter prima facie de los principios puede reforzarse introduciendo una carga de argumentación en favor de determinados principios o determinados tipos de principios. La decisión de incapacidad procesal ha mostrado que tanto las normas que conceden derechos fundamentales al individuo como las que ordenan la persecución de intereses de la comunidad, pueden ser concebidas como principios. Es posible introducir una carga de argumentación en beneficio de los principios del primer tipo y en contra de los del segundo, es decir, una carga de argumentación en beneficio de los bienes individuales y en contra de los bienes colectivos" (Teoría de los derechos fundamentales, p. 101). Em outro trabalho, como já informado, Alexy é enfático em estabelecer uma precedência prima facie em favor dos princípios relativos a direitos individuais em face dos princípios relativos a bens coletivos (El concepto y la validez del derecho, p. 207). O princípio da supremacia do interesse público faz justamente o contrário do sugerido por Alexy: ele introduz uma carga de argumentação em favor dos interesses coletivos. Ora, se não houvesse o princípio da supremacia do interesse público sobre o privado, as leis instituidoras de prerrogativas à Administração seriam todas inconstitucionais. Ademais, numa ponderação efetuada pelo administrador ou pelo juiz entre o interesse de apenas um particular e o interesse de muitos, o princípio da supremacia do interesse público dá primazia ao interesse de muitos. Isso não significa, porém, que sempre o interesse de muitos irá prevalecer: o interesse privado pode, diante das circunstâncias, apresentar-se tão pesado que afaste o interesse coletivo; além disso, a prevalência do interesse público não deve atentar contra o núcleo essencial dos direitos fundamentais.

70 A importância da decisão merece a transcrição: "A provocação formal que o Município de São Paulo deduziu a fls. 97/99 suscita o exame de relevante questão, pertinente à eficácia dos atos de comunicação processual, cujos destinatários sejam, como no caso, entes municipais. Como se sabe, os Municípios, em juízo ou fora dele, são representados, institucionalmente, por seus Prefeitos ou respectivos Procuradores municipais, consoante expressamente determinado pelo art. 12, II do CPC. Isso significa, portanto, que as intimações, em sede processual, para se reputarem válidas, notadamente quando se cuidar de entes estatais (como os

A\&C R. de Dir. Administrativo \& Constitucional, Belo Horizonte, ano 8, n. 33, p. 47-90, jul./set. 2008 
marco na Advocacia Pública, ela tornou expressa, de forma indiscutível, a diferença de regimes jurídicos entre a Advocacia Pública e a Privada. Percebase: desnecessário constar da publicação o nome do Procurador que atua no feito, basta a referência ao órgão (Procuradoria-Geral do Município); em certos casos, basta a referência à entidade coatora (Secretário de Finanças da Prefeitura do Município de São Paulo). Por decorrência lógica: se o Judiciário não é obrigado a intimar a pessoa do Procurador Municipal, há uma desvinculação entre o nome do Procurador e a publicação. Vigora o princípio da unidade institucional. Eis o problema: esses serviços de recortes do Diário Oficial prestados pelas entidades de classe, Associação de Advogados, OAB, tão essenciais para a advocacia privada, são imprestáveis para a Procuradoria. A posição jurisprudencial vigente cria um problema prático incontornável. Só há uma solução: a intimação pessoal da Fazenda.

Essa solução foi adotada no âmbito federal. O art. 38 da Lei Orgânica da Advocacia Geral da União (Lei Complementar no 73/93) determina que as intimações e notificações sejam feitas na pessoa do Advogado da

\footnotetext{
Municípios, p. ex.), deverão indicar o órgão que os represente, sob pena de absoluta ineficácia jurídica desse ato de cientificação. [...] Essencial, portanto, para efeito de válida intimação, que ao menos conste, da publicação oficial, a referência ao órgão (Advocacia-Geral da União, Procuradoria-Geral da Fazenda Nacional, Procuradoria-Geral do Estado, Procuradoria-Geral do Município, v.g.) investido da qualidade de representante legal da entidade de direito público, sem que seja necessário mencionar, para tal fim, o nome da pessoa titular de tais órgãos. Tal asserção nada mais reflete senão a própria prática processual que tem sido observada por esta Suprema Corte, como se observa do exame das publicações, com efeito de intimação, efetuadas em inúmeros processos que tramitam (ou tramitaram) perante o Supremo Tribunal Federal, e das quais apenas constou a menção aos órgãos de representação acima referidos (Al 374.002-AgR/SP, Rel. Min. IImar Galvão, DJU, p. 67, 22 ago. 2002 - Al 403.108/CE, Rel. Min. Ellen Gracie, DJU, p. 49, 16 nov. 2002- Al 406.601/RJ, Rel. Min. Gilmar Mendes, DJU, p. 78, 02 out. 2002- Al 346.420-AgR/RN, Rel. Min. Maurício Corrêa, DJU, p. 61, 12 abr. 2002, v.g). Esse entendimento - que impõe, pelo menos, a referência, no ato de comunicação processual, ao órgão representante (ou presentante) da entidade de direito público também encontra apoio na jurisprudência do E. Superior Tribunal de Justiça (REsp 29.050/MA, Rel. Min. Demócrito Reinaldo), que, a propósito do tema, firmou orientação em tal sentido: 'Processual Civil - Intimação - Publicação com o nome do cargo - Omissão do nome do titular - Precedente STJ. A intimação dirigida ao Estado, por seu Procurador-Geral, através de publicação em órgão oficial, não é nula, por isso que é possível a identificação das partes e seus procuradores. A omissão do nome do titular não impossibilitou a identificação da parte, atendendo a finalidade do ato, inexistindo dúvida quanto à pessoa e ao representante desta a serem intimados. Recurso especial não conhecido.' (RSTJ 132/234-235, Rel. Min. Francisco Peçanha Martins - grifei) Esta Suprema Corte, mesmo quando ausente a referência ao nome do Procurador ou ao órgão que ele integra, tem reconhecido, ainda assim, embora em caráter excepcional, a validade da intimação, desde que, consoante adverte a jurisprudência do Supremo Tribunal Federal (RE 71.143/MG, Rel. Min. Xavier De Albuquerque), a publicação do ato decisório indique, tratando-se de mandado de segurança (como no caso), a autoridade apontada como coatora - o 'Secretário das Finanças da Prefeitura do Município de São Paulo', na espécie (fls. 20 e 28): 'Mandado de segurança. Publicação da pauta sem indicação do nome do advogado do Município, designado para representá-lo no processo, mas com indicação da autoridade coatora, cujas informações constituem a única defesa do ato impugnado. Inaplicabilidade do art. $236, \$ 1^{\circ}$ do Código de Processo Civil. Nulidade não reconhecida.' (RE 81.582/PR, Rel. Min. Xavier De Albuquerque) [...] Embora as já referidas impugnações recursais houvessem sido deduzidas, consoante enfatizado, antes do ingresso do Município de São Paulo no referido processo de mandado de segurança, essa circunstância não tornava dispensável a referência, sempre necessária, ao órgão da Procuradoria-Geral do Município, legalmente incumbido do encargo de representá-lo em juízo (o Procurador-Geral do Município, na espécie). [...] Brasília, 06 de junho de 2003. Ministro Celso de Mello Relator. Decisão publicada em 11.6.2003".
} 
União ou do Procurador da Fazenda Nacional que oficie nos respectivos autos. Essa regra não foi expressamente estendida às Procuradorias Estaduais e Municipais, salvo para as execuções fiscais (Lei $n^{\circ} 6.830 / 80$, art. 25). A comunidade jurídica considera que, na falta de regra expressa, a intimação das Fazendas Estaduais e Municipais segue o regime geral do Código de Processo. Esse entendimento, apesar de pacificado, causa perplexidade: a diferenciação entre a defesa da União e a defesa dos Estados e Municípios não se fundamenta em critério razoável, pois os motivos que fundamentam a instituição dessa prerrogativa para a União igualmente existem para os Estados e Municípios. A não-extensão da intimação pessoal às Procuradorias Estaduais e Municipais importa em gritante violação do princípio da isonomia, do princípio federativo, pois diferencia arbitrariamente as entidades federativas, e do princípio da supremacia e indisponibilidade do interesse público, pois dificulta, e muitas vezes impossibilita, a defesa da Fazenda Estadual e Municipal. Tudo se resolve pela interpretação sistemática do sistema normativo: a regra do art. $3^{\circ}$ da revogada Lei $n^{\circ} 4.348$ / 64, a regra do art. 38 da vigente Lei Complementar $\mathrm{n}^{\circ} 73 / 93$ e a regra do art. 25 da vigente Lei $\mathrm{n}^{\circ} 6.830 / 80$, cujo preceito exige a intimação pessoal do procurador da Fazenda que atua no feito, encontram-se implícitas no sistema normativo e aplicam-se sempre que Administração Pública, federal, estadual ou municipal, autárquica ou fundacional, atue em juízo.

\subsection{Peculiaridades da antecipação de tutela}

Como regra geral, antes de conceder a antecipação de tutela em face da Administração Pública, deve o julgador ouvir o representante da Fazenda. ${ }^{71}$ Diante das circunstâncias, muitas vezes in status assertionis, o magistrado deve decidir se essa oitiva é ou não possível; se houver fundado receio de que o ilícito ou o dano venha a ocorrer em vinte quatro horas, impedido estará o magistrado de dar cumprimento a essa regra. Enfatizase: a regra da oitiva prévia do representante da Fazenda é uma razão prima facie, e não uma razão definitiva.

Além disso, os efeitos da antecipação da tutela deferida em face da Administração podem ser suspensos por meio do incidente de suspensão da execução, para evitar grave lesão à ordem pública, à saúde, à segurança

\footnotetext{
71 Essa regra está expressamente prevista no art. 928, parágrafo único, do CPC, para a expedição de mandado liminar de manutenção ou de reintegração de posse, e no art. $2^{\circ}$ da Lei $n^{\circ} 8.437 / 92$, para as medidas cautelares concedidas liminarmente em mandado de segurança coletivo e em ação civil pública. Curiosamente, a Lei no 9.494/97 não a estendeu à antecipação da tutela deferida contra a Fazenda. Apesar da omissão, é a ela aplicável, por analogia com os dois dispositivos mencionados.
}

A\&C R. de Dir. Administrativo \& Constitucional, Belo Horizonte, ano 8, n. 33, p. 47-90, jul./set. 2008 
e à economia pública. ${ }^{72}$ Ao condicionar a suspensão da segurança a esses objetivos, na verdade, o legislador está simplesmente determinando ao Presidente do Tribunal que, ao examinar a decisão proferida, observe o princípio da supremacia do interesse público sobre o privado, por força do qual, em abstrato, os interesses da coletividade têm uma razão prima facie maior nas ponderações efetuadas do que os interesses privados; diferença de peso, em abstrato, que pode inverter-se no caso concreto. Na verdade, como essas circunstâncias jurídicas também devem ser consideradas pelo magistrado, quando do exame do pedido de antecipação, o Presidente do Tribunal simplesmente revê a decisão tomada, quer dizer, a ponderação anteriormente efetuada pelo julgador que a deferiu. Nesses termos, ao estabelecer a finalidade da suspensão da execução o legislador cometeu evidente impropriedade.

Há várias restrições à utilização da antecipação jurisdicional da tutela contra a Fazenda Pública, muitas delas decorrentes de inequívoco desvio de poder legislativo, pois, em evidente vício de ponderação, dão excessiva importância à proteção dos supostos interesses fazendários. ${ }^{73}$ As principais restrições encontram-se consagradas na referida Lei Federal n ${ }^{\circ} 9.494$, de 10.09.1997, cuja constitucionalidade foi declarada pelo Supremo Tribunal Federal. ${ }^{74}$ Ela veda a antecipação nos casos de reclassificação

\footnotetext{
72 O incidente da suspensão da execução da medida liminar foi inicialmente previsto para o mandado de segurança no art. $4^{\circ}$ da Lei $n^{\circ} 4.348 / 64$. Por força desse dispositivo a Administração Pública ou quem a presente, para evitar grave lesão à ordem pública, à saúde, à segurança e à economia popular, pode requerer a suspensão da execução de medida liminar ao presidente do Tribunal competente para conhecer do respectivo recurso. Esse incidente foi posteriormente estendido pelo art. $12, \S 1^{\circ}$, da Lei $n^{\circ} 7.347 / 85$ ao mandado liminar concedido em ação civil pública; pelo art. 25 da Lei $n^{\circ}$ 8.038/90 à execução de liminar concedida pelo Tribunal em mandado de segurança; pelo art. $4^{\circ}$ da Lei no 8.437/92 à execução de cautelares; pelo art. $1^{\circ}$ da Lei $n^{\circ}$ 9.494/97 às antecipações de tutela deferidas contra a Fazenda Pública; pelo art. 16 da Lei $n^{\circ}$ 9.507/97 à concessão do habeas data. Sobre o tema, por todos, vide: RODRIGUES. Suspensão de Segurança: sustação da eficácia de decisão judicial proferida contra o Poder Público. Do conjunto desses dispositivos extrai-se a regra geral: toda a antecipação de tutela deferida em face da Administração Pública pode ser revista pela instância jurisdicional superior por meio do incidente de suspensão.

73 Sobre o desvio de poder legislativo existe clássico trabalho de TÁCITO, Caio. O desvio de poder no controle dos atos administrativos, legislativos e jurisdicionais. In: _. Temas de direito público: estudos e pareceres. Rio de Janeiro: Renovar, 1997. v. 1, p. 181-198. Afirma o excelso jurista: "Entendemos, em suma, que a validade da norma de lei, ato emanado do Legislativo, igualmente se vincula à observância da finalidade contida na norma constitucional que fundamenta o poder de legislar. O abuso do poder legislativo, quando excepcionalmente caracterizado, pelo exame dos motivos, é vício especial de inconstitucionalidade da lei pelo divórcio entre o endereço real da norma atributiva da competência e o uso ilícito que a coloca a serviço de interesse incompatível com a sua legítima destinação" (1997, p. 193).

74 BRASIL, Supremo Tribunal Federal. Plenário, ADC 4 MC/DF, Rel. Min. Sydney Sanches, j. 11.02.1998, v.m., DJ, p. 02, 21 maio 1999. Várias normas dessa lei, fruto da Medida Provisória no 1.570 diversas vezes reeditada, são inválidas por inconstitucionalidade, mas não é inválida a norma introduzia pela decisão do STF. No sistema jurídico, como dantes afirmado, existem regras que possibilitam atribuir validade a normas inválidas, são as chamadas regras de calibração, e o exemplo mais corriqueiro é a coisa julgada (FERRAZ JR. Teoria da norma jurídica, p. 131 et seq.). Perceba-se: a decisão do STF que declara a constitucionalidade de uma lei inconstitucional é válida por força da regra de calibração. Válida é a norma judicial, não a norma legal, esta permanece inválida, tanto que nada impede o STF de rever sua posição e reconhecer a invalidade da norma dantes declarada por ele válida.
} 
ou equiparação de servidores, concessão de aumento ou extensão de vantagens, exigindo que a decisão sobre essas matérias só gere efeitos após a decisão proferida pelo Tribunal, em sede de apelação. Todas as restrições impostas à tutela antecipatória geram razões prima facie, quer dizer, diante do exame do caso concreto podem ser afastadas pelo julgador.

Essa assertiva também se aplica ao regime de precatórios, fixado em regra constitucional concretizadora do princípio da impessoalidade. As regras constitucionais têm, em abstrato, grande peso, pois o princípio formal que dá primazia às ponderações constituintes é mais pesado do que o princípio formal que dá primazia às ponderações legislativas. Porém, ao colidir com princípios opostos, dependendo das circunstâncias fáticas e jurídicas, também as regras constitucionais podem ser afastadas. Por isso, dependendo do caso concreto, a exigência constitucional de submissão dos pagamentos em dinheiro pelo Estado ao regime de precatórios pode, sim, ser afastada. A Administração deve, por isso, prever em seu orçamento despesas extraordinárias decorrentes de antecipação de tutela, pois, diante do caso concreto, as exigências constitucionais de proteção da saúde ou segurança, por exemplo, podem ter tal peso que exijam a antecipação da tutela pecuniária, com afastamento das regras referentes à cobrança por precatório. Enfatiza-se, à guisa de conclusão: todos os obstáculos à antecipação da tutela em face da Fazenda Pública, fixados pelo constituinte ou pelo legislador, geram sempre razões prima facie, nunca razões definitivas.

\subsection{Informações da autoridade pública}

Em muitos casos a manifestação da autoridade competente pode afastar a invalidação de um ato administrativo. No exercício de competência discricionária, enquanto o móvel espúrio do agente público faz presumir de forma absoluta o vício de finalidade, ${ }^{75} \mathrm{o}$ erro gera apenas presunção relativa. Assim, se o agente público, em fundamentação exaustiva, demonstrar que, segundo seu juízo, consideradas as verdadeiras circunstâncias fáticas e jurídicas, a solução adotada é a que melhor atende o interesse público, afastada estará a invalidação. Ademais, as informações podem evitar a imposição de obrigações de fazer: se a política governamental está em fase de implementação, se o projeto está em fase de execução, não há sentido na imposição jurisdicional.

\footnotetext{
75 Sobre o tema vide, por todos: BANDEIRA DE MELLO. Ato administrativo e direito dos administrados, p. 69-72.
}

A\&C R. de Dir. Administrativo \& Constitucional, Belo Horizonte, ano 8, n. 33, p. 47-90, jul./set. 2008 
Por certo, a manifestação da autoridade coatora é, em certos casos, de extraordinária importância para o controle da antijuridicidade da função pública. Por isso, independente do rito e do objeto da ação, sempre que o magistrado verificar que a oitiva da autoridade é relevante, deverá requerer sua manifestação. Perceba-se que a regra extraída do art. $7^{\circ}$, I, da revogada Lei $n^{\circ} 1.533 / 51$ e do art. $1^{\circ}$, “a”, da também revogada Lei $n^{\circ} 4.348 / 64$ sofre significativos temperamentos no regime geral das ações movidas em face da Administração Pública. Não faz sentido impor a apresentação de informações em todos os casos. Nas questões tributárias, por exemplo, quando o fundamento da ação é a inconstitucionalidade da cobrança, as informações pouco acrescentam. Quando desenvolvidas pela autoridade, repetem a defesa da Fazenda Pública. Comumente são elaboradas pelo próprio procurador que atua no feito. Na ausência de regra expressa, considerandose revogada a lei do Mandado de Segurança, extrai-se do sistema, por meio da interpretação sistemática, uma regra mais racional: as informações da autoridade devem ser requeridas pelo magistrado, quando consideradas relevantes para o exame da juridicidade do exercício da função pública.

O magistrado deve decidir se as informações podem ser apresentadas junto com a defesa da Fazenda, no prazo de 60 dias, ou se devem ser apresentadas em prazo menor, no prazo de 10 dias, por exemplo. A fixação do prazo não deve ser arbitrária, deve ser ditada pela finalidade do ato: se a apresentação das informações destina-se, por exemplo, a apurar a necessidade de antecipação de obrigação de fazer, dependendo das circunstâncias, é impossível aguardar a defesa da Fazenda sem grave prejuízo ao interesse tutelado. Ao determinar a citação do ente público, no mesmo despacho, o magistrado decide sobre a apresentação das informações da autoridade coatora: se elas devem ou não ser apresentadas e em qual prazo.

As informações possuem, basicamente, duas funções: 1) fornecer razões para manutenção do ato no sistema normativo; 2) fornecer dados sobre as providências administrativas adotadas pelo ente público. Podemse fixar as seguintes diretrizes: no caso de atos administrativos inválidos, se num primeiro golpe de vista houver indícios do exercício de competência discricionária, a apresentação faz-se sempre necessária, nos casos em que, in status assertionis, visualiza-se o exercício de competência vinculada, compete ao magistrado ponderar se as informações são ou não necessárias, vale dizer, a pertinência da oitiva da autoridade coatora deve ser avaliada pelo magistrado; no caso de omissão administrativa, como regra geral, as

A\&C R. de Dir. Administrativo \& Constitucional, Belo Horizonte, ano 8, n. 33, p. 47-90, jul./set. 2008 
informações fazem-se sempre necessárias. Nos casos em que as informações podem afastar a invalidação do ato, a não apresentação importa na invalidação; nos casos em que as informações podem afastar a imposição de obrigação de fazer, a não apresentação importa na imposição da obrigação.

Em suma: deve-se ler o Código de Processo Civil com a advertência de que ele foi pensado para as relações civis. Por isso, da análise sistemática, extrai-se um conjunto de regras implícitas, constitutivas do regime jurídico das ações que tenham por objeto o exercício da função pública. Da correta interpretação do sistema constata-se a inexistência de dois regimes distintos de tutela jurisdicional mandamental em face da Administração Pública: não há um regime especial, previsto na Lei do Mandado de Segurança, e um regime geral, previsto no Código de Processo. A lei especial referida foi retirada do sistema no momento em que a tutela nela proporcionada foi estendida ao rito ordinário. De outro lado, o rito ordinário nas ações relativas ao exercício da função pública especializa-se.

A proposta de compreensão do sistema jurídico processual, desenvolvida neste estudo, não é de lege ferenda, mas de lege lata. É bem provável que ela encontre acentuada resistência dos juristas ainda apegados ao legalismo, exigentes de regras legislativas expressas. Diante da antevista resistência, termina-se este estudo com as advertências de dois notáveis juristas. Celso Antônio Bandeira de Mello a sabendas averbou: "Não se deve interpretar uma garantia constitucional à luz do processo, mas as vias processuais à luz do texto constitucional". E pouco adiante: "As vias processuais são vestes, são como trajes que revestem o direito quando precisa ser defendido". ${ }^{76} \mathrm{Em}$ assonância, para finalizar este estudo registra-se a oportuna observação de Sérgio Ferraz: "O juiz serve-se do Código de Processo Civil, mas não serve ao Código de Processo Civil”. ${ }^{77}$

\section{Conclusões}

1 Se o Direito Administrativo é um meio de proteção do cidadão, o mandado de segurança é o instituto que faz essa proteção real. Ao examinar o mandado de segurança sob a perspectiva histórica o jurista percebe, de modo surpreendentemente claro, como a aludida proteção foi ficando mais sólida, como a arma e o escudo do cidadão foram se tornando mais eficazes e mais poderosos.

\footnotetext{
$76 \mathrm{O}$ ato coator. In: BANDEIRA DE MELLO (Org.). Curso de mandado de segurança, p. 20.

77 Aspectos processuais do mandado de segurança. In: BANDEIRA DE MELLO (Coord.). Curso de mandado de segurança, p. 131
}

A\&C R. de Dir. Administrativo \& Constitucional, Belo Horizonte, ano 8, n. 33, p. 47-90, jul./set. 2008 
2 Para os atos do Estado, desde cedo, os juristas clamaram por uma tutela contra o ilícito, discrepante da regra em vigor no sistema, de restrição à tutela contra o dano. Logo no início do período republicano foi promulgada a Lei $\mathrm{n}^{\circ} 221$, que previu a chamada ação sumária especial. Tratava-se de diploma normativo inegavelmente à frente do Direito da época, anacronismo esse que provavelmente foi a causa de sua ineficácia. Diante do insucesso da Lei $n^{\circ} 221$ surgiram duas correntes: uma de orientação civilista, pela qual a tutela jurisdicional contra o ilícito estatal dava-se pelos interditos possessórios; outra de orientação publicista, pela qual essa tutela dava-se pelo habeas corpus. A Reforma Constitucional de 1926 importou no sepultamento da doutrina brasileira do habeas corpus; como a orientação civilista estava, praticamente, superada, a modificação do texto constitucional importou numa verdadeira lacuna de tutela jurisdicional.

3 O mandado de segurança, positivado no art. 113, 33, da Constituição de 1934, foi a solução para essa lacuna. Diante da redação do dispositivo, a edição de uma lei infraconstitucional era desnecessária, mas o legislador editou a Lei ${ }^{\circ}$ 191/36: estabeleceu um rito especial, instituiu um prazo decadencial e vedou a concessão da segurança em algumas hipóteses. A disciplina da Lei $\mathrm{n}^{\circ}$ 191, em linhas gerais, foi repetida no CPC de 1939 e, posteriormente, na Lei $n^{\circ} 1.533 / 51$. Ressalvada a Constituição de 1937, todas as Constituições posteriores mantiveram essa garantia constitucional. Na Constituição vigente, de 1988, o mandado de segurança encontra-se positivado nos incisos LXIX e LXX do art. $5^{\circ}$. Outrora ninguém apontava a inconstitucionalidade das restrições legais; hoje, apostilas desse teor podem ser colhidas aos racimos.

4 Apesar dos avanços, faz-se necessário ir além: tomar a expressão "conceder mandado de segurança" como julgar procedente a ação legalmente prevista com esse nome é padecer do mal do legalismo, é entender o texto constitucional a partir do texto legislativo. A compreensão do tema deve ser buscada no próprio texto constitucional, e o ponto de partida é o signo mandado: "conceder-se-á mandado de segurança" significa mandar alguém fazer alguma coisa. O sentido é completado pela expressão "para proteger direito": o mandamus busca evitar a prática de um ilícito, sua continuação ou sua repetição e eliminar ou remover a situação de ilicitude, não pretende reparar o dano. Eis o núcleo essencial do mandado de segurança: a autoridade jurisdicional expedirá uma ordem à autoridade competente para que ela não pratique a ilicitude e, se esta já foi praticada, para que ela adote as medidas necessárias à remoção da ilicitude.

A\&C R. de Dir. Administrativo \& Constitucional, Belo Horizonte, ano 8, n. 33, p. 47-90, jul./set. 2008 
5 Até bem pouco tempo, a tutela contra o ilícito era excepcional, a regra era a tutela contra o dano. O mandado de segurança consistia numa exceção do sistema. Ocorre que o direito processual brasileiro sofreu verdadeira revolução conceitual. O marco desse avanço foi a Lei $\mathrm{n}^{\circ}$ 8.952/94, que deu nova redação aos arts. 273 e 461 do Código de Processo Civil vigente (Lei $\left.\mathrm{n}^{\mathrm{o}} 5.869 / 1973\right)$, possibilitando ao magistrado, independentemente da natureza do direito, no rito ordinário, antecipar a tutela jurisdicional e garantir a tutela específica. Ambos os dispositivos modificaram as bases do processo civil brasileiro: a tutela contra o ilícito deixou de ser exceção, passou a ser vulgarmente admitida, podendo ser pleiteada no rito ordinário. A tutela mandamental passou a ser possível nos casos em que a ilicitude não seja praticada por agente público e, mais, nos casos em que não haja direito líquido e certo. A revolução conceitual mencionada decorreu da promulgação de leis ordinárias, infraconstitucionais; contudo, os institutos da antecipação de tutela e da tutela da obrigação específica passaram a ser considerados desdobramentos do princípio constitucional da efetividade da tutela jurisdicional.

6 O inciso LXIX do artigo $5^{\circ}$ da Constituição da República de 1988 não garante a propositura da ação prevista infraconstitucionalmente na Lei $\mathrm{n}^{\circ} 1.533 / 51$, garante a tutela mandamental para proteção de direito. Com as modificações do Código de Processo a tutela mandamental tornouse ordinária, foi estendida ao procedimento ordinário. Concluiu-se: o rito especial previsto na Lei $n^{\circ} 1.533 / 51$ não subsiste no sistema normativo. Sem embargo, o inciso LXIX do art. $5^{\circ}$ do Texto Maior não tem apenas função enfática: o dispositivo alarga, quando se trata do exercício da função pública, as hipóteses de antecipação de tutela. $\mathrm{O}$ valor do dispositivo não está, propriamente, na expressão "conceder-se-á mandado de segurança para proteção de direito", porque essa expressão é uma decorrência implícita do princípio da efetividade da tutela jurisdicional; seu valor está no complemento: "para proteção de direito líquido e certo".

7 Pelo art. 273 do CPC, a antecipação de tutela pode ser deferida em duas hipóteses. Na primeira, quando estiverem presentes dois pressupostos: a) verossimilhança da alegação; b) fundado receio de dano irreparável ou de difícil reparação ou caracterização do abuso do direito de defesa ou do manifesto propósito protelatório do réu. Na segunda, quando um ou mais dos pedidos cumulados, ou parcela deles, mostrar-se incontroverso. Para o exercício da função, além dessas hipóteses, há outra: quando houver direito com base fática demonstrável de plano, sem necessidade de dilação probatória (direito líquido e certo) e o magistrado entender que diante da

A\&C R. de Dir. Administrativo \& Constitucional, Belo Horizonte, ano 8, n. 33, p. 47-90, jul./set. 2008 
plausibilidade do direito invocado não se faz necessário, para o deferimento da tutela, ler as informações da autoridade coatora, a defesa da Fazenda e o parecer do Ministério Público.

8 Para comprovar o acerto da tese proposta, a retirada da Lei $\mathrm{n}^{\circ}$ 1.533/51 em decorrência do avanço científico, pela incompatibilidade lógica com esse avanço, supôs-se sua incorreção. Admitiu-se, seguindo a doutrina e a jurisprudência, que a Lei $\mathrm{n}^{\mathrm{O}} 1.533 / 51$ subsiste no sistema normativo. Configurado o direito líquido e certo, o administrado possuiria duas medidas jurisdicionais de impugnação da ilegalidade ou do abuso de poder praticado pelo agente público: poderia impetrar mandado de segurança pelo rito especial da Lei $\mathrm{n}^{\circ} 1.533 / 51$ ou propor ação de cumprimento de obrigação de fazer, com pedido de antecipação de tutela, pelo rito ordinário. Em ambas as vias obtém-se igual tutela jurisdicional, a tutela mandamental, em ambas há possibilidade de antecipação da tutela, os efeitos proporcionados pelo rito ordinário e especial são, no caso, exatamente os mesmos. O regime processual, porém, é sensivelmente distinto, e a adoção de um ou outro regime depende da vontade do administrado, basta a escolha do rótulo: mandado de segurança ou ação de rito ordinário com pedido de antecipação de tutela. Essa solução, concluiu-se, apesar de pacificamente adotada pela comunidade jurídica, é incorreta: o exame da juridicidade da função pública não diz respeito apenas ao interesse privado do beneficiado ou prejudicado, a função pública, por definição, concretiza o interesse público e, por isso, o regime de seu controle não pode ficar subordinado à vontade do particular.

9 Houve, de fato, a retirada do mundo jurídico da Lei $\mathrm{n}^{\circ} 1.533 / 51$ e, por conseguinte, inexiste duplicidade de ritos, ordinário e especial, para o exame da juridicidade da função pública. Contudo, concluiu-se, o rito ordinário, quando tem por objeto o exame da função pública, de certa forma especializase, torna-se um rito especial, por força do interesse público inerente a esse exame e das particularidades da Fazenda Pública. Apresentaram-se, então, os traços gerais do regime das ações que tenham por objeto o exame do exercício da função pública. Dos conceitos de função administrativa e jurisdicional e da relação entre ambas, concluiu-se: a suspensão dos efeitos da sentença só pode ser obtida pela Administração Pública mediante decisão jurisdicional autônoma, de natureza cautelatória, que tenha por conteúdo essa suspensão, jamais decorrerá automaticamente da mera interposição do recurso. Da apurada compreensão do texto constitucional, concluiu-se: o Ministério Público deve intervir como fiscal da lei em todas as ações em que a Administração Pública seja parte. Outrossim, as peculiaridades da

A\&C R. de Dir. Administrativo \& Constitucional, Belo Horizonte, ano 8, n. 33, p. 47-90, jul./set. 2008 
Fazenda Pública justificam certas prerrogativas processuais: em todas as ações, independentemente do rito, ela tem prazo em quádruplo para contestar e em dobro parar recorrer; em todas as ações ela é intimada pessoalmente dos atos processuais. Ademais, em decorrência do princípio da supremacia do interesse público sobre o privado, a antecipação de tutela em face da Fazenda apresenta algumas peculiaridades: como regra geral, antes de conceder a antecipação de tutela em face da Administração Pública, deve o julgador ouvir o representante da Fazenda; toda a antecipação de tutela deferida em face da Administração Pública pode ser revista pela instância jurisdicional superior por meio do incidente de suspensão; há no sistema normativo restrições à antecipação da tutela em face da Fazenda Pública geradoras de razões prima facie - todas elas, dependendo das circunstâncias do caso concreto, podem ser afastadas pelo julgador. Finalmente, em todas as ações movidas em face da Administração deve o magistrado decidir sobre a necessidade ou não da manifestação da autoridade coatora e, havendo necessidade, deve fixar o prazo para apresentação das informações.

\begin{abstract}
The writ of mandamus must be understood in light of the words contained in the Constitution, and not in the ordinary legislation. Subsection LXIX of Article 5 of the Brazilian Federal Constitution does not ensure the legal action provided for by Law $1.533 / 51$, which is a law hierarchically inferior to the Constitution; it rather ensures the writ of mandamus as the appropriate remedy for the protection of a right. After the modifications brought by the Brazilian Code of Civil Procedure, the writ of mandamus was added to the ordinary proceeding. Consequently, the special proceeding set out by Law 1.533/51 cannot survive within the normative system. Nevertheless, the constitutional provision has not only an emphatic function: for the public function to be exercised, besides the possibilities of granting the interim relief stipulated by Section 273 of the Brazilian Code of Civil Procedure, a third possibility is added: when the case presents an ascertained and unquestionable right and the court holds that, in view of the plausibility of the right claimed, in order for the relief to be granted, neither the information (answer) provided by the infringing authority, nor the answer presented by the Treasury Department, nor the opinion issued by the Public Attorney's Office need to be read.
\end{abstract}

Keywords: Writ of mandamus. Interim relief. Jurisdictional control of the public function.

\title{
Referências
}

ALEXY, Robert. El concepto y la validez del derecho. Traducción Jorge M. Seña. 2. ed. Barcelona: Gedisa, 2004.

ALEXY, Robert. Teoría de los derechos fundamentales. Tradução de Ernesto Garzón Valdés. 1. ed., 3. reimpr. Madrid: Centro de Estudios Políticos y Constitucionales, 2002.

A\&C R. de Dir. Administrativo \& Constitucional, Belo Horizonte, ano 8, n. 33, p. 47-90, jul./set. 2008 
ALVIM, Arruda. Tratado de direito processual civil. 2. ed. São Paulo: Revista dos Tribunais, 1990. v. 1 .

BANDEIRA DE MELLO, Celso Antônio. Ato administrativo e direito dos administrados. São Paulo: Revista dos Tribunais, 1981.

BANDEIRA DE MELLO, Celso Antônio. Curso de direito administrativo. 22. ed., rev. e atual. São Paulo: Malheiros, 2007.

BANDEIRA DE MELLO, Celso Antônio. Direito a férias anuais. Revista de Direito Público, São Paulo, ano 21, n. 85, p. 157-160, jan./mar. 1988.

BANDEIRA DE MELLO, Celso Antônio. Discricionariedade e controle jurisdicional. 2. ed., 2. tiragem. São Paulo: Malheiros, 1996.

BANDEIRA DE MELLO, Celso Antônio. Juízo liminar, poder-dever de exercício do poder cautelar nessa matéria. Revista Trimestral de Direito Público, São Paulo, n. 3, p. 106-116, 1993.

BANDEIRA DE MELLO, Celso Antônio. Mandado de segurança contra denegação ou concessão de liminar. Revista de Direito Público, São Paulo, ano 22, n. 92, p. 55-61, out./ dez. 1989.

BANDEIRA DE MELLO, Celso Antônio. O ato coator. In: de segurança. São Paulo: Revista dos Tribunais, 1986. p. 7-37.

(Org.). Curso de mandado

BARBI, Celso Agrícola. Do mandado de segurança. 10. ed. Rio de Janeiro: Forense, 2000.

BARBOSA, Rui. Posse dos direitos pessoais. São Paulo: Saraiva, 1986. (Clássicos do Direito Brasileiro; v. 6).

BUENO, Cássio Scarpinella. Liminar em mandado de segurança: um tema com variações. 2. ed. rev., atual. e ampl. São Paulo: Revista dos Tribunais, 1999.

BUZAID, Alfredo. Do mandado de segurança. São Paulo: Saraiva, 1989.

CAVALCANTI, Themístocles Brandão. Do mandado de segurança. 4. ed. Rio de Janeiro: Freitas Bastos, 1957.

DALLARI, Adilson Abreu. A autoridade coatora. In: BANDEIRA DE MELLO, Celso Antônio (Org.). Curso de mandado de segurança. São Paulo: Revista dos Tribunais, 1986. p. 38-68.

DIAS, Francisco Barros. Mandado de segurança e decadência: inconstitucionalidade do art. 18 da Lei 1.533/51. Revista Trimestral de Direito Público, São Paulo, v. 4, p. 195-198, 1993.

FERRAZ JR., Tércio Sampaio. Introdução ao estudo do direito. 2. ed. São Paulo: Atlas, 1995.

FERRAZ JR., Tércio Sampaio. Teoria da norma jurídica. 4. ed. Rio de Janeiro: Forense, 2002.

FERRAZ, Sérgio. Aspectos processuais do mandado de segurança. In: BANDEIRA DE MELLO, Celso Antônio (Coord.). Curso de mandado de segurança. São Paulo: Revista dos Tribunais, 1986. p. 128-145.

FERRAZ, Sérgio. Mandado de segurança. São Paulo: Malheiros, 2006.

FIGUEIREDO, Lúcia Valle. Mandado de segurança. 4. ed. São Paulo: Malheiros, 2002.

GIANESINI, Rita. Tutela antecipada e execução provisória contra a Fazenda Pública. In: SUNDFELD, Carlos Ari; BUENO, Cassio Scarpinella (Coord.). Direito processual público. São Paulo: Malheiros, 2000. p. 170-180.

GRINOVER, Ada Pellegrini et al. Código brasileiro de defesa do consumidor: comentado pelos autores do anteprojeto. 5. ed. Rio de Janeiro: Forense Universitária, 1998.

LUCAS VERDÚ, Pablo. O sentimento constitucional: aproximação ao estudo do sentir constitucional como modo de integração política. Tradução de Agassiz Almeida Filho. Rio de Janeiro: Forense, 2004.

A\&C R. de Dir. Administrativo \& Constitucional, Belo Horizonte, ano 8, n. 33, p. 47-90, jul./set. 2008 
MARINONI, Luiz Guilherme. A antecipação da tutela na reforma do processo civil. 2. ed. rev. e ampl. São Paulo: Malheiros, 1996.

MARINONI, Luiz Guilherme. Técnica processual e tutela dos direitos. São Paulo: Revista dos Tribunais, 2004.

MARINONI, Luiz Guilherme. Tutela cautelar e tutela antecipatória. São Paulo: Revista dos Tribunais, 1992.

MARINONI, Luiz Guilherme. Tutela específica: arts. 461, CPC e 84, CDC. São Paulo: Revista dos Tribunais, 2001.

MARTINS, Ricardo Marcondes. Efeitos dos vícios do ato administrativo. São Paulo: Malheiros, 2008.

MARTINS, Ricardo Marcondes. Prescrição da pretensão tributária. Revista Tributária e de Finanças Públicas, São Paulo, ano 16, v. 78, p. 202-233, jan./fev. 2008.

MAZZILI, Hugo Nigro. Regime jurídico do Ministério Público. 3. ed. rev., ampl. e atual. São Paulo: Saraiva, 1996.

MEIRELLES, Hely Lopes. Mandado de segurança. 17. ed. São Paulo: Malheiros, 1996.

MIRANDA, Jorge. Manual de direito constitucional. 4. ed. rev. e atual. Coimbra: Coimbra Ed., 2000. Tomo II - Constituição.

MIRANDA, Pontes de. História e prática do habeas corpus. Campinas: Bookseller, 2001. tomo I.

MIRANDA, Pontes de. Tratado das ações. Campinas: Bookseller, 1998. tomo I.

MORAES, José Roberto de. As prerrogativas e o interesse da Fazenda Pública. In: SUNDFELD, Carlos Ari; BUENO, Cassio Scarpinella (Coord.). Direito processual público. São Paulo: Malheiros, 2000. p. 66-78.

NUNES, José de Castro. Do mandado de segurança. 7. ed. Rio de Janeiro: Forense, 1967.

PERELMAN, Chaïm. Ética e direito. Tradução de Maria Ermantina Galvão. São Paulo: Martins Fontes, 2002.

RODRIGUES, Marcelo Abelha. Suspensão de segurança: sustação da eficácia de decisão judicial proferida contra o Poder Público. São Paulo: Revista dos Tribunais, 2000.

SILVA, José Afonso da. A advocacia pública e estado democrático de direito. Revista de Direito Administrativo, Rio de Janeiro, v. 230, p. 281-289, out./dez. 2002.

SILVA, Ovídio A. Baptista da. Curso de processo civil. 5. ed. São Paulo: Revista dos Tribunais, 2002. v. 2.

SILVA, Ovídio A. Baptista da. Do processo cautelar. 2. ed. Rio de Janeiro: Forense, 1998.

SILVA, Ovídio A. Baptista da. Processo e ideologia. 2. ed. Rio de Janeiro: Forense, 2006. p. 200.

THEODORO JÚNIOR, Humberto. Curso de direito processual civil. 33. ed. Rio de Janeiro: Forense, 2002. v. 2.

VELLOSO, Carlos Mário da Silva. Conceito de direito líquido e certo. In: BANDEIRA DE MELLO, Celso Antônio (Org.). Curso de mandado de segurança. São Paulo: Revista dos Tribunais, 1986. p. 67-100.

VIANA, Juvêncio Vasconcelos. Efetividade do processo em face da Fazenda Pública. São Paulo: Dialética, 2003.

Informação bibliográfica deste texto, conforme a NBR 6023:2002 da Associação Brasileira de Normas Técnicas (ABNT):

MARTINS, Ricardo Marcondes. A teoria do mandado de segurança diante da evolução do direito processual civil. A\&C Revista de Direito Administrativo \& Constitucional, Belo Horizonte, ano 8, n. 33, p. 47-90, jul./set. 2008.

A\&C R. de Dir. Administrativo \& Constitucional, Belo Horizonte, ano 8, n. 33, p. 47-90, jul./set. 2008 